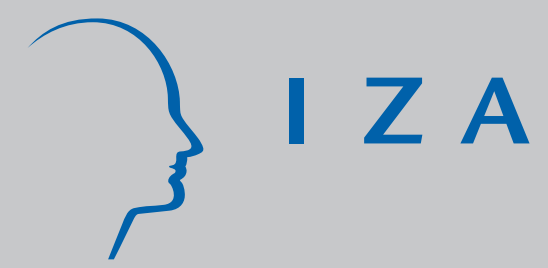

IZA DP No. 7204

UK Households' Carbon Footprint: A Comparison of the Association between Household Characteristics and Emissions from Home Energy, Transport and Other Goods and Services

Milena Buchs

Sylke V. Schnepf

February 2013 


\title{
UK Households' Carbon Footprint: A Comparison of the Association between Household Characteristics and Emissions from Home Energy, Transport and Other Goods and Services
}

\author{
Milena Buchs \\ University of Southampton \\ Sylke V. Schnepf \\ University of Southampton \\ and IZA \\ Discussion Paper No. 7204 \\ February 2013 \\ IZA \\ P.O. Box 7240 \\ 53072 Bonn \\ Germany \\ Phone: +49-228-3894-0 \\ Fax: +49-228-3894-180 \\ E-mail: iza@iza.org
}

\begin{abstract}
Any opinions expressed here are those of the author(s) and not those of IZA. Research published in this series may include views on policy, but the institute itself takes no institutional policy positions. The IZA research network is committed to the IZA Guiding Principles of Research Integrity.

The Institute for the Study of Labor (IZA) in Bonn is a local and virtual international research center and a place of communication between science, politics and business. IZA is an independent nonprofit organization supported by Deutsche Post Foundation. The center is associated with the University of Bonn and offers a stimulating research environment through its international network, workshops and conferences, data service, project support, research visits and doctoral program. IZA engages in (i) original and internationally competitive research in all fields of labor economics, (ii) development of policy concepts, and (iii) dissemination of research results and concepts to the interested public.
\end{abstract}

IZA Discussion Papers often represent preliminary work and are circulated to encourage discussion. Citation of such a paper should account for its provisional character. A revised version may be available directly from the author. 


\section{ABSTRACT \\ UK Households' Carbon Footprint: A Comparison of the Association between Household Characteristics and Emissions from Home Energy, Transport and Other Goods and Services ${ }^{1}$}

Does the association between household characteristics and household $\mathrm{CO}_{2}$ emissions differ for different areas such as home energy, transport, indirect and total emissions in the UK? Specific types of households might be more likely to have high emissions in some areas than in others and thus be affected differently by climate mitigation policies that target these areas. Using the Living Costs and Food Survey and Expenditure and Food Survey for the years 2006 to 2009, this paper compares how household characteristics like income, household size, rural/urban location and education level differ in their association with home energy, transport, indirect and total emissions. We find that the association between household characteristics and emissions differs considerably across these areas, particularly for income, education, the presence of children, female headed, workless and rural households. We also test the implicit assumption in the literature that the association between household characteristics and $\mathrm{CO}_{2}$ emission is constant across the $\mathrm{CO}_{2}$ emission distribution using quantile regressions and compare results for poor and rich households. The analysis considers policy implications of these findings throughout.

JEL Classification: D12, D31, D60, H20, Q01

Keywords: carbon dioxide emissions, inequality, climate change mitigation policies, living costs and food survey, United Kingdom

Corresponding author:

Sylke Viola Schnepf

Faculty of Social and Human Sciences and S3RI

University of Southampton

Southampton SO17 1BJ

United Kingdom

E-mail: svs@soton.ac.uk

\footnotetext{
${ }^{1}$ The research on which this report is based was funded by the ESRC, grant RES-000-22-4083 for which we would like to express our gratitude. Many thanks also to Frederico de Luca for research assistance in preparing the dataset, and to John Micklewright and Nicholas Bardsley for helpful comments on an earlier version of this paper.
} 


\section{$1 \quad$ Introduction}

There is a general consensus in the scientific community that further policy measures need to be

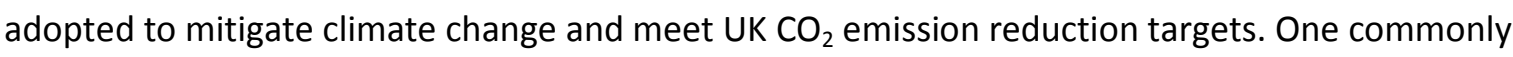
perceived problem of carbon reduction policies such as carbon taxes is that they have regressive effects as low income households are likely to bear a higher financial burden as a proportion of their income than high income households. It is therefore an important task to establish how potentially regressive effects of carbon reduction policies can be minimised. For doing so we do need to know in detail which role household characteristics play for emissions in each of these areas. Most policies rely on financial incentives to encourage emission reductions. Therefore, household income, expenditure and household size have been among the most important factors for examining unequal distributions of emissions as well as distributional implications of abatement policies. However, household characteristics other than income might well contribute to higher or lower emissions independently from income. If this is the case, these characteristics would also matter for the distributional implications of mitigation policies independently from household income and size. To examine whether household characteristics other than income and household size matter for emissions, we need to examine the effects of household characteristics conditional on all other factors by applying regression analysis.

In recent years, several studies have been published on the distribution of household emissions $^{2}$ and the role of socio-economic factors for the UK (e.g. Baiocchi et al., 2010; Brand and Boardman, 2008; Brand and Preston, 2010; DEFRA, 2008; Dresner and Ekins, 2006; Druckman and Jackson, 2008; Druckman and Jackson, 2009; Fahmy et al., 2011; Gough et al., 2011) and for other countries (see Girod and De Haan, 2010; Kerkhof et al., 2009; Weber and Matthews, 2008; Wier et al., 2001). Of these studies for the non-UK context, Kerkhof (2009) and Weber and Matthews (2008) compare unconditional associations for different types of emissions and only Weber and Matthew's study (ibid.) examines conditional associations between household characteristics and emissions. However, they only do that for total $\mathrm{CO}_{2}$ emissions and do not compare differences between emission domains.

For the UK, there are several studies that examine unconditional or conditional associations between household characteristics and emissions but none of them compares regression results across different domains of $\mathrm{CO}_{2}$ emissions. For example, Baiocchi et al. (2010) conduct OLS

\footnotetext{
${ }^{2}$ Here, we only list studies on household emissions. Whilst some studies have conducted distributional analysis of household energy (rather than emissions) (e.g. Burney, 1995; Cohen et al., 2005; Herendeen and Tanaka, 1976; Herendeen et al., 1981; Larivière and Lafrance, 1999; Lenzen et al., 2006; O'Neill and Chen, 2002; Pachauri, 2004; Reinders et al., 2003; Vringer and Blok, 1995), none of them compares associations between emissions/energy and household characteristics using multivariate analysis, comparing different areas of emissions.
} 
regression to examine determinants of total $\mathrm{CO}_{2}$ emissions using the census-based ACORN database. The studies by Brand and Boardman (2008) and Brand and Preston (2010) focus on the role of household characteristics for transport $\mathrm{CO}_{2}$ emissions, based on their own survey from a sample in Oxfordshire. Studies by DEFRA (2008) and Fahmy et al. (2011) focus on the role of household characteristics for the total of home energy and motor fuel/transport $\mathrm{CO}_{2}$ emissions and Dresner and Ekins (2006) cover home energy only. Druckman and Jackson analyse home energy (2008) and total emissions (2009) at the small area level and for seven household types based on output area classification super groups and do not examine conditional associations. Gough et al. (2011) do apply OLS regression to compare different areas of emissions, but the study focuses on greenhouse gases rather than $\mathrm{CO}_{2}$. It also does not include factors such as education, rural and urban location or gender (variables central for our analysis).

This paper contributes to the literature by comparing the role of household characteristics for different areas of $\mathrm{CO}_{2}$ emissions in the UK. We analyse and compare the association of household size, age, socio-economic background and housing characteristics with home energy (gas, electricity, oil, coal and other heating fuels), transport (motor fuels, public transport and flights) and indirect (food and other goods and services) household $\mathrm{CO}_{2}$ emissions. ${ }^{3}$ Emissions in these three areas will also be compared to households' total emissions summarising emissions of the three areas.

Existing studies (e.g. Baiocchi et al., 2010; DEFRA, 2008; Gough et al., 2011) that use least square regressions implicitly assume that the impact of household characteristics on emissions is constant across the emission distribution. An additional value added of this paper is the examination of whether this assumption holds using quantile regressions. Furthermore, we compare OLS regression results for poor and rich households separately to examine in more detail which characteristics make poorer households more likely to bear larger burdens from mitigation policies.

Our analysis is based on representative expenditure surveys in the UK, the Living Costs and Food Survey (LCF) and its predecessor the Expenditure and Food Survey (EFS), merged over the years 2006 to 2009 and combined with different data sources to estimate household $\mathrm{CO}_{2}$ emissions based on expenditure data.

Our analysis follows three steps. First, we examine the association between household characteristics and $\mathrm{CO}_{2}$ emissions. This enables us to answer questions such as: how are household characteristics like household size and composition, income, age, education, ethnicity and gender of the household reference person (defined as the person paying the rent or mortgage or, if this is shared, the person with the higher income) related to emissions in the three areas? Does rural location matter equally for home energy and transport emissions?

\footnotetext{
${ }^{3}$ Even though emissions from electricity are "indirect" emissions, we allocate them to home energy emissions as this is more meaningful from a policy perspective.
} 
Given that many characteristics are highly correlated (i.e. income and education), we examine in a second step whether characteristics like education or rural location still matter for explaining $\mathrm{CO}_{2}$ emissions once income is controlled for applying OLS regressions.

The use of OLS regressions assumes that the impact of household characteristics is similar across the distribution of $\mathrm{CO}_{2}$ emissions. In a third step, we demonstrate that while this assumption is generally true for many variables, some household characteristics like education and rural location differ in their importance for explaining $\mathrm{CO}_{2}$ emissions at the top and the bottom of the emission distribution.

For all three steps, we will compare results across the three emission areas and for total emissions so that we can identify which households might be hardest hit by carbon reduction policies targeting these areas.

The paper first describes the data and limitations on which the analysis is based (section 2). This is followed by quantifying $\mathrm{CO}_{2}$ emissions in the three areas and relating those to household characteristics in section 3. Regression results will be presented in section 4 . Section 5 concludes.

\section{Data and limitations}

\subsection{Data}

For the UK there is currently no representative $\mathrm{CO}_{2}$ emissions dataset at the household level available. Research on the distribution of emissions across households thus relies on other data sources to estimate household emissions. In this paper, we convert rich information on households' expenditure into $\mathrm{CO}_{2}$ estimates. Our household expenditure data derive from the merged UK Living Costs and Food Survey (LCF) for the years 2008 and 2009 and its predecessor, the Expenditure and Food Survey (EFS), for the years 2006 and 2007 which provides us with a total household sample size of 24,446 . The LCF/EFS is an annual survey, covering detailed information on expenditure for a large number of consumer items and services according to the Classification of Individual Consumption According to Purpose (COICOP) and a range of socio-economic variables. We convert households' expenditure into $\mathrm{CO}_{2}$ emission estimates using the following methods.

For home energy we use Tables 2.2.3 and 2.3.3 of the Quarterly Energy Prices statistics by the Department for Energy and Climate Change (DECC, 2011a, b) providing us with information on annual domestic electricity and gas prices per kWh, including standing charge and VAT, for three payment methods and each electricity/gas region. Since the LCF/EFS includes variables on payment method and region, we can link this information to estimate units of energy consumption for piped gas and electricity. In addition, our home energy $\mathrm{CO}_{2}$ estimates include emissions from heating oil, bottled gas, coal and wood which comprise 10.4 per cent of the UK households' $\mathrm{CO}_{2}$ home energy 
emissions estimate. Here we use DECC price statistics on petroleum products and Sutherland (2012) tables to convert expenditure into units of consumption.

For transport $\mathrm{CO}_{2}$ emissions we estimate litres of motor fuel (petrol and diesel) consumed using AA statistics (AA, 2006-2009) of monthly motor fuel prices for each government region. For public transport we estimate kilometres travelled employing information on average annual passenger miles for train, tube, bus and coach journeys from the National Travel Survey for Great Britain (DfT, 2011: table NTS0305) and the Northern Ireland Travel Survey for Northern Ireland (DRDNI, 2011: table 3.1). Flight emissions are estimated by approximating flight kilometres merging information from the LCF/EFS survey on the number of person flights per household within the UK, Europe and outside Europe with average distance for flights to these destinations calculated using the NTS and the International Passenger Survey. DECC $\mathrm{CO}_{2}$ conversion factors (DECC and DEFRA, 2011) provided for different fuels and modes of transport are then applied to units of consumption of home energy, litres of motor fuels and kilometres travelled by mode of transport to estimate $\mathrm{CO}_{2}$ emissions.

To estimate indirect emissions we use the Resources and Energy Analysis Programme (REAP) database which provides estimates of total $\mathrm{CO}_{2}$ emissions arising from consumption by UK households of 57 COICOP categories in 2006 (Paul et al., 2010). These data are employed to generate $\mathrm{CO}_{2}$ per pound expenditure factors for 49 consumption categories which we apply to household expenditure (inflation corrected for 2007-2009) to estimate emissions (using the methods described above for the remaining categories).

Based on these conversions of expenditure to carbon dioxide estimates, our mean annual total estimate of household $\mathrm{CO}_{2}$ emissions across the 4 years is 513 million tonnes compared to 527 million tonnes according to DECC's (production based) estimate for the same period (DECC, 2012: table 1). Baiocchi et al. (2010: 57) arrive at an estimate of 505 million tonnes of $\mathrm{CO}_{2}$ for UK household emissions in 2000 and Druckman and Jackson (2009: 2072) estimate 560 million tonnes $\mathrm{CO}_{2}$ in 2004 (neither these nor our study take government and capital investment emissions into account). Our per household $\mathrm{CO}_{2}$ estimates of 20.2 tonnes (standard error 0.13 ) compares to 20.8 tonnes derived from DECC (2012: table 1) for 2006 to 2009 and to 21.5 tonnes for 2004 by Druckman and Jackson (2009: 2072) who use previous rounds of the EFS but slightly different methods for estimating emissions. Discrepancies of estimates are likely to stem from different data sources, coverage and methods of conversion. For a detailed discussion of how we converted household expenditure data to $\mathrm{CO}_{2}$ emission for different areas and how different estimates compare see (Buchs and Schnepf, 2013) . 


\subsection{Limitations}

Estimating emissions based on household expenditure is limited in several ways. The first problem is that we would need to know more precisely how much and what people consume to estimate emissions whilst the LCF/EFS only records expenditure. For example, for home energy the LCF/EFS does not record the energy provider or tariff which would be required to match prices more precisely (even though as discussed before it provides the payment method and area which reflect important differences in prices); for public transport tickets and flights it does not record the exact destinations and type of ticket (first or second class or reductions for pre-booking or railcards). The LCF/EFS also only records expenditure for relatively broad consumption categories but not the brand or origin which could tell us more about a product's potential carbon content. However, even if more detailed information on consumption were available, we would not be able to match it with more precise emission factors due to a lack of data.

This relates to a second problem that we call the 'product quality problem'. This is important for our analysis because different types of households may differ in their choice of product in ways that we cannot observe even though it is relevant for estimating emissions. For example, $f 10$ spent by one household on a high quality product, for example organic local cheese, might relate to lower $\mathrm{CO}_{2}$ emissions than $\mathrm{f10}$ spent by another household on a low quality, mass produced cheese imported from another country. Since high income households tend to spend more on high quality products than low income households, this could lead to an overestimation of emissions from high income households if higher spending does not translate into proportionally higher emissions (Girod and De Haan, 2010). This might be especially the case for flight and public transport emissions (higher income households might be less inclined to choose budget airlines and pre-booked tickets but more first class tickets). Recently, Girod and Haan (2010: 43) found that the elasticity of household emissions in Switzerland and expenditure was reduced from 1.06 to 0.53 when they compared an expenditure-based to a units of consumption-based model for emissions. However, they concede that this estimate might be 'optimistic, because higher quality goods might also lead to higher impact' (ibid.). This links to research by Hurth (2010) who found that high-end supermarket food products targeting affluent consumers consistently had higher carbon packaging and cites evidence that wealthy consumers find it difficult to choose lower-carbon options if these products conflict with their identities. As a consequence, given the lack of literature examining the association between higher spending and $\mathrm{CO}_{2}$ emission content of products by household characteristics, we currently cannot clearly state whether our $\mathrm{CO}_{2}$ estimates are systematically biased for households with different socio-economic characteristics. 
A third limitation results from the 'infrequency of purchase problem'. The LCF/EFS collects expenditure data through a survey for more infrequent purchases such as electricity and gas bills, cars, season tickets and package holidays. In general, the period that the survey covers for these items refers to the last payment period, quarterly or annual expenditure. However, some more frequent expenditure items are only collected through two-week diaries kept by each household member. For all these purchases, expenditure estimates might be affected by the infrequency of purchase problem. This is a very common problem that studies on household expenditure are confronted with (Tiffin and Arnoult, 2010) but so far it has not been discussed in detail in the literature on expenditure based emission estimates.

In our case, the infrequency of purchase problem reflects two important issues. First, we aim at examining annual $\mathrm{CO}_{2}$ emissions, but have measurement of expenditure for many items only for a two week time period. Hence, some people who did not consume an item in a two week period might have had expenditure of this item during the last year. We can demonstrate this problem in relation to private flights as the LCF/EFS collects both expenditure on flights from the diary and the number of flights in the last year through the survey. Only 1.3 per cent of all households have an expenditure on flights within two weeks but 41.0 per cent of households record at least one flight during the last year. Since flight emissions are an important source of $\mathrm{CO}_{2}$ emissions and we estimate annual $\mathrm{CO}_{2}$ emissions we use the number of flights instead of expenditure data to estimate flight emissions.

Second, while people might not have an expenditure on an item during two weeks, they may still have consumed this item from stocks during the diary window. We can demonstrate this problem by comparing our data on motor fuels to data from the National Travel Survey (NTS) which records both expenditure on motor fuels from a diary and an estimate of annual mileage driven by car based on a household survey. 18.2 per cent of LCF/EFS households who own or use a vehicle did not purchase any motor fuel during the two-week period. According to the NTS, 39 per cent of households who have or use a vehicle did not purchase any fuel during the one-week diary period but only $1 \%$ of all households said they did not travel by car during the last year according to the survey. While the NTS estimate of 39 per cent of 'zero' spending for a one week period comes close to our LCF estimate of 18 per cent for a two week period, the NTS results also suggest that a considerable part of these zero expenditures might be 'false' as the vast majority of the households with access to vehicles used them throughout the year. An expenditure-based estimate would thus incorrectly assume zero annual emissions.

The infrequency of purchase problem affects those expenditures covered by the two weekdiaries. For our $\mathrm{CO}_{2}$ transport estimate this regards motor fuels and public transport which 
contribute 74.3 per cent of our total transport $\mathrm{CO}_{2}$ estimate (the rest deriving from flights) and 16.2 per cent of our total $\mathrm{CO}_{2} \mathrm{UK}$ estimate. As a consequence, our transport $\mathrm{CO}_{2}$ emission estimate is likely to be affected by the infrequency of purchase problem. On the other hand, for home energy the problem is less relevant with heating fuels collected through the diary such as bottled gas, coal, wood and peat contributing only 0.8 per cent to total emissions while prepayment electricity is only used by 15.0 and gas pre-payments by 12.2 per cent of households with access to mains gas (mains gas, electricity and heating oil purchases are recorded through the household survey). All indirect $\mathrm{CO}_{2}$ emission estimates are based on diary data. Depending on the product focused on, frequencies for expenditure differ largely with 'only' 0.7 per cent of households not having had any expenditure on food during two weeks but 32.6 per cent of households without expenditure on clothing (see Table 1).

Does the infrequency of purchase problem affect our analysis? All previous studies using expenditure data for estimating $\mathrm{CO}_{2}$ emissions implicitly or explicitly (DEFRA, 2008: 13) assume that $\mathrm{CO}_{2}$ estimates based on diary data provide correct mean values as zero expenditure from infrequently purchased items should be compensated by expenditures higher than the actual consumption rate of those households who stock up during the diary period. However, measures of dispersion such as standard deviation and variance are likely to be overestimated. Given that we conduct OLS regressions and experience the measurement error in the dependent variable, we need to be aware that standard errors of coefficients are likely to be inflated.

There is no obvious reason to assume that the assumption of error cancelling out does not hold for our data. We examined this issue further and could not find a consistent relationship between infrequency of purchase and household characteristics like household income. In the econometric literature focusing on the examination of expenditure patterns, models have been developed that recover artificially censored data due to infrequency of purchase. In particular, the pTobit model (Deaton and Irish, 1984) is based on a two-equation structure with a binary estimate of the likelihood of spending, followed by a tobit of the spending level that includes zero spending. However, more recent literature questions the reliability of such models (Gibson and Kim, 2012). In the following, we therefore assume - in line with existing literature - that measurement errors cancel out for means, totals and regression coefficients. Once focusing on the area of transport emissions - which is the only one where we expect bigger problems of zero-spending - we analyse the probability of having transport $\mathrm{CO}_{2}$ emissions and the determinants of $\mathrm{CO}_{2}$ emissions for households with transport expenditure separately. 


\section{Home energy, transport and indirect $\mathrm{CO}_{2}$ emissions and their association with household characteristics - unconditional results}

\section{1 $\mathrm{CO}_{2}$ emissions in the UK by emission area}

Table 1 shows mean and median household $\mathrm{CO}_{2}$ emissions in our pooled sample, together with the per cent of an area's or item's contribution to overall $\mathrm{CO}_{2}$ emissions and the per cent of households without emissions. The distribution of $\mathrm{CO}_{2}$ emissions for all three areas shows a strong positive skew given that the mean is considerably higher than the median. In order to interpret the size of skew, the most obvious comparator is household income. The ratio of the UK weekly income mean to the median is 1.25 for 2009/10 (DWP, 2011: 28). This is relatively similar to the skew we see for home energy (1.14), indirect emissions (1.23) and $\mathrm{CO}_{2}$ emissions in total (1.18). However, the skew of transport emissions is considerably higher (1.48) as well as that for single categories of indirect emissions (like for example clothing, recreation, furniture and personal care). To a certain extent, the high skew for transport might be explained by the infrequency of purchase problem discussed above: first, more than half of transport emissions derive from two week data which are converted into annual data; second, transport expenditures are relatively infrequent, reflected by the per cent of households without expenditure.

According to our study, median UK household emissions are 17.1 tonnes of $\mathrm{CO}_{2}$ emission per year whilst the mean is as high as 20.2 tonnes. 5.1 tonnes or 25.3 per cent of total emissions derive from home energy whereby piped gas contributes 12.3 per cent and electricity 10.4 per cent of an average household's emissions. 4.4 tonnes or 21.8 per cent of total household emissions originate from transport, consisting of flights that contribute 5.6 per cent on average to a household's total emissions. This figure is high given that it relates to an annual mean of 0.6 private flights per person or 1.3 per household. The remainder of total emissions, 10.7 tonnes or 52.9 per cent are indirect emissions incorporated in other goods and services consumed. This category also includes emissions arising in the production of heating and motor fuels (12.9 per cent) as well as 'other' indirect categories (12.6 per cent) such as medical care and hospital services, telephone and postal services and cosmetics.

These results compare well with Druckman and Jackson's (2009: 2075) study who find that heating and other home energy fuels together contribute 27 per cent and commuting (similar to our "motor fuel" category) 9 per cent to households' carbon footprint in 2004. Baiocchi et al. (2010: 57) also find that private vehicle emissions contribute 12.8 per cent to households' $\mathrm{CO}_{2}$ emissions in 2000 whilst 'direct home energy' only contributes 17 per cent. Here it is unclear whether they count electricity as direct or indirect emissions. Our result also differs from Gough et al. (2011: 8) who find that direct emissions (here defined as household fuels, electricity and motor fuels (ibid: 4)) only 
contribute 20 per cent to households' total emissions. However, their indirect emissions might be higher because they include other greenhouse gases and modes of transport other than private car travel in this category.

\section{2 $\mathrm{CO}_{2}$ emissions and household size}

Carbon reduction policies can target households or individuals. Household size and composition is thus important for potential distributional implications. For example, studies on Personal Carbon Allowances or similar policies have to make assumptions about the allocation per person in each household (DEFRA, 2008: 66f.; Gough et al., 2011: 34ff.; Starkey, 2012). Previous literature has shown that household size is an important factor for household emissions and that there are economies of scale once individuals share household resources (DEFRA, 2008: 5; Druckman and Jackson, 2008: 3184; Gough et al., 2011: 13f.). However, the extent of economies of scale has not yet been compared in detail for different areas of emissions. On the role of children, Baiocchi et al. (2010: 64) find that households with children have lower $\mathrm{CO}_{2}$ emissions than those without, holding other factors constant, a finding not confirmed by our data (see section 4). DEFRA (2008: 20f.) found that per adult emissions rise with the number of children whilst the increase of emissions was found to be modest and not significant for more than two children. Gough et al. $(2011: 13,26)$ found that households with children have lower per capita emissions both conditional and unconditional, which is to be expected because children are likely to consume less than adults.

Table 2 presents average $\mathrm{CO}_{2}$ emissions for different household types: the first four rows present results for single, two, three and four adult households (all without children and adults defined to be 18 years or older). The last three rows refer to two adult households with one, two or three children. Most interestingly, on average, two adult households have almost three times higher $\mathrm{CO}_{2}$ emissions on transport than single adult households (4.9 compared to 1.8 tonnes $\mathrm{CO}_{2}$ ). One reason for this sharp increase is that 33 per cent of single adult households (of which 50 per cent are 62 year old or older) do not have any transport emissions compared to just 9 per cent of two, 4 per cent of three and 1 per cent of four adult households (all without children). Also indirect emissions double for a two adult household, which might not be very surprising given that goods for which we would assume economies of scale due to sharing (e.g. furniture and appliances) only represent a small share of the total indirect $\mathrm{CO}_{2}$ emissions (see Table 1). In contrast to transport and indirect emissions, $\mathrm{CO}_{2}$ emissions for home energy increase by less than 50 per cent when we compare one to two-adult households. This indicates that economies of scale mainly exist for this area of emissions. Focusing on total $\mathrm{CO}_{2}$ emissions, each individual in a two-adult household has on average per capita $\mathrm{CO}_{2}$ emissions equal to that of a one adult household, which is quite a different pattern to 
what income equivalence scales would suggest: for instance, the modified OECD scale widely used for poverty research weights the second adult by 0.5 instead of a value of 1 which our analysis would suggest for emissions. However, per capita emissions decrease considerably compared to that of a single adult household once adult household size rises beyond two. On average, a three adult household has only about a 28 per cent higher $\mathrm{CO}_{2}$ emission than a two adult household, and also transport and indirect emissions increase by 35 and 30 per cent respectively. This picture is similar when we compare a four with a three adult household.

Surprisingly, however, the additional contribution to $\mathrm{CO}_{2}$ emissions by children in the household is much smaller than any equivalence scale from poverty research would suggest. Whilst two adult households with one child have significantly higher emissions (at least at the $5 \%$ level) than two adult households without a child, the increase is relatively small with 15 per cent for total, 20 for indirect, 7 for home energy and 11 per cent for transport.

These results indicate that any equal per adult emissions trading scheme that assumes an allocation to children of 50 (Gough et al., 2011: 36) or 30 (DEFRA, 2008) per cent of a full adult permit would be beneficial for households with more than two adults as well as households with children since $\mathrm{CO}_{2}$ emissions increase by much less with additional household members than the scheme suggests, especially for home energy.

\section{3 $\mathrm{CO}_{2}$ emissions and income}

Income is a well-known determinant of $\mathrm{CO}_{2}$ emissions (e.g. Baiocchi et al., 2010; Brand and Boardman, 2008; DEFRA, 2008; Gough et al., 2011; Weber and Matthews, 2008). This is not surprising: $\mathrm{CO}_{2}$ emissions arise from household consumption and are correlated with disposable income (in the LCF/EFS with $r=0.7$ (excluding the $1^{\text {st }}$ and $99^{\text {th }}$ percentile of the emissions and income distribution). The more income you have the more likely you are to spend. However, expenditure translates quite differently into $\mathrm{CO}_{2}$ emissions for varying consumption categories: one pound of expenditure translates into a lower value for $\mathrm{CO}_{2}$ emission for indirect emission than for home energy or transport (see Buchs and Schnepf, 2013).

All studies that investigate income conclude that emissions rise with income (Baiocchi et al., 2010; Brand and Boardman, 2008; DEFRA, 2008; Druckman and Jackson, 2008; Fahmy et al., 2011; Gough et al., 2011; Weber and Matthews, 2008). However, not much is currently known about the way in which the association between income and emissions differs for individual areas of emissions as these studies investigate specific areas of emissions in separation. For example, Druckman and Jackson (2008: 3183f.) and Dresner and Ekins (2006: 52) found a positive correlation between income and home energy emissions; DEFRA (2008: 19f.) and Fahmy et al. (2011: 17f.) find an 
increase of home energy and transport emissions combined with rising income; Brand et al. (2008: 232f.; 2010: 15) report a high correlation between income and transport emissions. However, when controlling for other variables, Brand and Preston (2010:16) only find a significant relationship between income and flight emissions, but not for emissions from car travel. Baiocchi et al. (2010: 62) confirm significant positive relationship between income and total household $\mathrm{CO}_{2}$ emissions and Gough et al. (2011: 11) for total and individual areas of greenhouse gas emissions.

Our data enable us to compare the association between income and $\mathrm{CO}_{2}$ emissions in the areas of home energy, indirect, transport and total emissions. This is relevant if we want to know more about potential distributional implications of carbon reduction policies that target different areas of emissions. For example, do emissions rise evenly with income in the different areas or not? If not, are emissions progressively distributed over income in any of these areas (as, for example, Dresner and Ekins (2004: 25) found for motor fuel)?

Figure 1 plots the mean household carbon dioxide emissions against equivalised household income (using the modified OECD scale) by emission area (all households are included whether or not they had $\mathrm{CO}_{2}$ emissions in that area). Given the high variation of $\mathrm{CO}_{2}$ emissions across 24,446 households, we calculate mean emissions for mean equalised income for 10 income deciles. The 10 data points are then connected with a line for each emission area. The data are plotted on log scales. This makes it easier to compare the proportional change for $\mathrm{CO}_{2}$ emissions and hence to judge whether emissions in different areas are more or less responsive to changes in income. The proportional changes are also the basis for the classification of policy impact as regressive and progressive. The slashed line on the diagram represents a 1 per cent increase in $\mathrm{CO}_{2}$ emissions for a 1 per cent increase in income. Any parallel line would reflect this 1 per cent increase. If the data points rise more steeply than the 1 per cent line, emission are classified to be progressive in economic terms, if the line rises less steeply they are regressive.

If we disregard the 10 per cent of households with annual equivalised household income below $£ 6,200$ and the 20 per cent of households with highest equivalised annual income (above $f 19,800$ ), the transport data series is roughly parallel to the 1 per cent share line, indicating that transport $\mathrm{CO}_{2}$ emissions are almost proportional to income. In contrast, the line is much flatter for home energy, indicating that $\mathrm{CO}_{2}$ emissions are most regressively distributed compared to other areas. Indirect emissions also show a regressive increase with income but less so than home energy emissions.

We conduct OLS regression in order to quantify the steepness of the lines presented in Figure 1 using log of $\mathrm{CO}_{2}$ emissions as dependent and log of annual equivalised household income as only explanatory variable. Using this regression design, the coefficient of the income variable 
provides the income elasticity. If the coefficient equals 1 , a one per cent increase in equivalised income relates to a 1 per cent $\mathrm{CO}_{2}$ emissions increase, reflecting exactly the relationship given by the elasticity line in Figure 1. Regression results show that a 1 per cent increase in equivalised income increase of $\mathrm{CO}_{2}$ emissions for home energy by 0.28 , indirect emissions by 0.69 and transport emissions by 0.88 per cent. (For transport, households without emissions are excluded from the regression model, while they are included in Figure 1. This is one explanation why we do not find a coefficient closer to 1.) This indicates that whatever emission area a policy would focus on, the policy is likely to disadvantage low income households more than high income households in relative terms. However, if carbon reduction policies were to focus on transport $\mathrm{CO}_{2}$ emissions, low income households would be hit less than if the policies included other types of emissions.

Up to now, we argued that the association between income and $\mathrm{CO}_{2}$ emissions is important given the possible implications of carbon reduction policies for poor and rich households. This links to another widely discussed topic in the literature on carbon emissions: that of justice and equality. For example, it is often considered unfair (e.g. Baer et al., 2008) to demand from developing countries to restrict their carbon emissions since it is developed countries who are responsible for the bulk of existing emissions up to date (which is why developing countries have not been part of the Kyoto agreement and might not be part of any binding future agreements to come). A similar argument can be applied to the $\mathrm{CO}_{2}$ emission distribution within a country. For example, our data show that 25 per cent of the poorest households (with equivalised household income at or below the $25^{\text {th }}$ percentile) emit only 15 per cent of the UK's total household $\mathrm{CO}_{2}$ emissions, while the 25 per cent richest households (with equivalised household incomes at or above the $75^{\text {th }}$ percentile) emit as much as 37 per cent of the UK total. If households restricted themselves to $\mathrm{CO}_{2}$ emissions equal to that of poor households, average UK household emissions would decrease from 20.2 to about 12.1 tonnes and total annual UK household emissions from 513 to 306 million tonnes. If achieved by 2020 and compared to a baseline of 586 million tonnes in 1990 (DECC, 2012), this would equate to a reduction by 48 per cent to the 1990 baseline - much more drastic than the currently envisaged reduction of 20 per cent by 2020 that the European Union subscribed to. Again, this relates back to policy implications of carbon reduction policies, highlighting issues around fairness if low income households are penalised.

Of great interest are the high discrepancies of emission inequalities by income for different areas. For home energy, the poorest 25 per cent emit 20 per cent of total home energy emissions and are therefore closer to the 25 per cent of emissions we would expect. Rich households emit 30 per cent. For indirect emissions, the differences in the shares of emissions between poor and rich 
households are much larger (14 to 38 per cent), and they are highest for transport emissions (11 per cent compared to 42 per cent).

We also calculated the tax burden from a hypothetical tax of $£ 100$ per one tonne of carbon dioxide emission. We expressed this tax burden as proportion of equivalised household income. As expected, results confirmed the regressiveness of carbon taxes, showing that households in the lowest equivalised income decile would lose 5.6 per cent of their income from taxes on home energy, 7.6 for indirect, 2.0 for transport and 15.3 per cent for taxes on total emissions. This compares to 1.1 per cent, 2.9 per cent, 1.4 per cent and 5.3 per cent respectively for households in the highest equivalised income decile.

So far, our discussion of the association between income and $\mathrm{CO}_{2}$ emissions focused on average household emissions by income. However, this view disguises that emissions can considerably vary between households within the same income range. This means that a considerable proportion of low income households may still have high emissions. Even if emissions were progressively distributed, these households would bear a high financial burden by policies that put a price on carbon.

Table 3 sheds light on this by providing the percentage of households within different groups having low (equal or below the $25^{\text {th }}$ percentile of emissions) or high $\mathrm{CO}_{2}$ emissions (equal or above the $75^{\text {th }}$ percentile of emission) by emission area. (We include 0 emissions for the calculation of quartiles.) If household characteristics were not related to $\mathrm{CO}_{2}$ emissions, all cells in Table 3 would show a percentage of 25 . First, we just focus on the first two rows providing information for poor and rich households (defined as households in the lowest and highest equivalised income quartile). For example, 7 per cent of low income households are in the upper quartile of indirect $\mathrm{CO}_{2}$ emissions, while 53 per cent are situated in the lowest quartile (the remaining 40 per cent of households have emissions above the $25^{\text {th }}$ and below the $75^{\text {th }}$ percentile). These figures are similar for transport emissions. However, as many as 17 per cent of low income households have high home energy $\mathrm{CO}_{2}$ emissions, highlighting again that taxes on home energy are likely to be much more regressive than those on transport. Whilst there are some low income households with very high emissions, there is also a small share of high income households with low emissions. Around 5-7 per cent of high income households have low indirect and transport emissions, but 15 per cent have low home energy emissions. On the other hand, around half of high income households have high transport and indirect emissions.

In addition, we can analyse the variation of emissions within income deciles. For example, home energy emissions at the $80^{\text {th }}$ emissions percentile within the lowest equivalised income decile are 1.7 times higher than those at the $20^{\text {th }}$ emissions percentile in the highest income decile. For 
home energy, the $20 / 80$ ratio of emissions is also much wider within the lowest income decile compared to that for all households: 6.5 compared to 2.9. Even though this pattern is less pronounced for transport, indirect and total emissions, households equal to or above the $80^{\text {th }}$ emissions percentile in the lowest income decile only have modestly lower emissions than households equal to or below the $20^{\text {th }}$ emissions percentile in the highest income decile for these categories - around 17 per cent less for total and indirect and 16 per cent less for transport emissions. This provides further evidence that taxes on home energy are likely to cause higher financial burdens for some low income than some high income households not only in relative but also in absolute terms whilst this is not the case for policies that put a price on transport or total emissions.

\section{4 $\quad \mathrm{CO}_{2}$ emissions and other household characteristics}

The fact that emissions vary considerably within income deciles suggests that a range of other household characteristics are also important for household emissions. This section investigates which other factors are associated with $\mathrm{CO}_{2}$ emissions besides income. Table 3 shows that education plays an important role for high emissions. Only 14 per cent of households in which none of the members attended full time education for more than 11 years (education<11) are in the highest emissions quartile, compared to 44 per cent of households in which at least one member participated in full time education for 16 or more years (education16+). The results also show that rural households and households with children are more likely than urban households and households without children to belong to the highest emissions quartile. Conversely, households with younger or older reference persons, workless households (defined as households without a working age adult being in employment), households with female reference persons (39 per cent of our sample) and ethnic minority households (defined not to be 'white') are less likely to be in the highest emissions quartile.

The results in this table also illustrate that the high likelihood to have high emissions for households with high incomes, high education and with children is mainly driven by high indirect and high transport emissions. Conversely, households with older reference persons, workless households and female headed households are much more likely to have high home energy emissions relative to other types of emissions, demonstrating their potential vulnerability to home energy taxes.

The last five rows of Table 3 provide information on the type of dwelling. We would assume that home energy emissions are highest for detached houses compared to purpose built flats as shown in previous research (DEFRA, 2008: 22). Indeed, 54 per cent of households residing in purpose built flats have low home energy emissions but only 11 per cent of households in detached houses. 
Most of the variables focused on in this table are highly correlated with each other. For example, type of dwelling, education and employment status are all highly related to income. Once the income effect is taken into account, the association of these variables with $\mathrm{CO}_{2}$ emissions might differ considerably depending on which emission area we focus on. This will be examined in greater detail in section 4 using OLS regression.

\subsection{Who has transport emissions?}

Up to now, transport emissions stood out with a highly positive skew, a high percentage of households not having any transport emissions and highest income elasticities. In addition, two of our three transport components - motor fuels and public transport - derive from diary data, making transport estimates more susceptible to potential problems of infrequency of purchase which cannot be quantified as discussed above. So far, none of the papers using the LCF/EFS examine the role of household or individual characteristics for transport emissions in greater detail (but see the papers by Brand et al. (2008; 2010) who have used their own survey covering Oxfordshire).

Figures reported so far focused on total transport emissions. In this section, we examine participation in the three subcategories of transport, based on household expenditure on motor fuels and public transport (both collected over a two week diary) and expenditure on flights in the last 12 months (collected over the survey).

Even though the collection period for data regarding the three transport categories differs, we do find that different means of transport are highly clustered. In total, 15 per cent of households do not have any expenditure on transport and 21 per cent participated in all three modes of transport. About 43 per cent of households that have an expenditure for public transport and motor fuels did not fly during the past 12 months. This compares to almost 60 per cent of all households that did not have a flight (see Table 1). Conversely, 26 per cent of households who had a flight in the last year did not purchase any motor fuel and 39 per cent did not use public transport. This compares to 36 per cent and 50 per cent for all households. As a consequence, households using one mode of transport have a higher probability of using another mode in addition. This is an encouraging result in terms of the methodological problem of merging two week diary data with annual flight data. Since participation in different modes of transport is clustered, we are more likely to include most of the people who had some form of transport in our overall transport emission variable. In addition, it could indicate that household characteristics play a similar role for choosing different modes of transport.

Table 4 examines this issue in greater detail fitting a logistic regression model. A logistic regression model for $p$, the probability of having transport emissions, may be written as 
$p(y)=1 /\{1+\exp (-\beta X)\}$ where $X$ is a vector of observable household characteristics. Estimates of the parameters $\beta$ were obtained by maximum likelihood. When a variable $X_{j}$ is continuous, the partial derivative of $p$ with respect to $X_{j}$ is $(p(1-p)) \beta_{j}$. This may be interpreted as a marginal effect on the response probability of small changes in $X_{j}$ but is a function of $p$ which in turn depends on particular values of $X_{j}$. As a suitable overall summary measure, we report below calculations of this expression when $p$ is set to the sample proportion of individuals who have transport emissions (see Table 1). For a binary variable, $\mathrm{X}_{\mathrm{j}}$ is an approximation to summarizing discrete changes in probability in moving from $X_{j}=0$ to $X_{j}=1$, which again would strictly depend on all variables in $\mathbf{X}$.

We examine the impact of household size using dummy variables for the number of adults (adult5 representing households with 5 or more adults) and children (child3 for households with 3 or more children) in the household. The coefficient measures the additional effect of an adult in the household, i.e. adult2 is set to 1 for all households with at least two adults. Additional adults increase the household's probability of having motor fuel and public transport expenditure compared to a single adult household. The marginal effect of the second adult compared to oneadult households on the probability of purchasing motor fuels is quite high with about 20 per cent ( $p$ set to 0.64 ) (whilst it is only 5 percentage points for public transport with $p$ set to 0.50 ). However, if anything, household size decreases rather than increases the probability of flying (by 3 percentage points, but only significant at the $5 \%$ level, p set to 0.41 ). Income seems to have the highest 'impact' on flight probability, compared to motor fuel and public transport which reflects that flights are more expensive and likely to be a 'luxury' good. For examining the relationship between age and the probability to participate in transport, we used the variable 'age' giving the household reference person's age, the square age divided by 100 and a dummy variable indicating whether the age is above 80 (the latter is necessary since the age variable was top coded to 80 ). Age seems most relevant for motor fuel expenditure, but less for flights, and is insignificant for public transport. Interestingly, conditional on income, education does still matter for explaining participation in all three modes of transport, particularly for air travel and overall transport. A household where at least one member participated in full-time education for 16 or more years has a 17 percentage point higher probability of flying than a household in which no member has attended full time education for more than 11 years even if income is controlled for ( $p$ set to 0.41 ). Workless households are more likely to choose public transport and less likely to use private vehicles or flights than other households. And finally, the probability of using motor fuels for households living in rural areas (defined as settlements with a population of less than 10,000) is 14 percentage points higher than that of an urban household conditional on all other factors (with $p$ at 0.64 ). This is likely to reflect a dependence on private vehicles for mobility in rural areas, especially since those households are also 
less likely to participate in public transport. In addition, their probability of air travel is about 4 percentage points lower compared to urban households ( $p$ set to 0.41 ).

In summary, we find that some household characteristics play a similar role for the probability to participate in all three modes of transport: with increasing education and income the probability of using any of the three transport modes increases. Hence, similar to unconditional results presented above, these households are more likely to have higher transport $\mathrm{CO}_{2}$ emissions. Other characteristics relate differently to transport modes: i.e. rural location and household size seem mostly relevant for private vehicle use but not for air travel. This might indicate that rural households only have limited choice over their motor fuel emissions, which on average contribute 14 per cent to rural households' total $\mathrm{CO}_{2}$ emissions (not shown in Table).

These results are also important for the next section which examines the conditional association between household characteristics and different types of emissions because households without any expenditure and thus 'zero' emissions are excluded from the analysis. The last column of Table 1 shows us that 15.2 per cent of households have not participated in any mode of travel. As a consequence, by excluding households without emissions, our sample for total transport emissions will include fewer households with single adults, lower income, higher age, lower education and urban households compared to the full sample.

\section{Conditional associations between household characteristics and $\mathrm{CO}_{2}$ emissions}

\subsection{OLS regression}

Results in section 3 demonstrated that income plays an important role for carbon dioxide emissions for all emission areas. In addition, we found that households with highly educated, 'middle aged', employed and male reference persons and those located in rural areas all have a higher likelihood to have high $\mathrm{CO}_{2}$ emissions for one or several emission areas. But many of these characteristics are highly correlated with income which raises the question whether they still play a significant role for emissions once income is controlled for. This is also relevant from a policy perspective: since many carbon reduction policies are likely to increase financial incentives for emissions reduction, we need to ask whether these monetary effects might significantly affect specific groups in society after we control for income. For example, whilst less regressive carbon taxes such as those on transport may seem attractive from a fairness perspective, they may still be problematic if transport emissions are not only driven by income but also by other characteristics. If rural location still matters after controlling for income, this may indicate limited opportunities for rural households to reduce their motor fuel emissions, likely to decrease the effectiveness of motor fuel taxes unless public transport becomes more available in those areas. 
In Table 5, we present OLS regression results examining the significance of household characteristics in determining households' $\mathrm{CO}_{2}$ emissions conditional on income. In section 3 , we already reported the regression coefficient for the natural logarithm of equivalised income if this is used as the only independent variable for explaining $\mathrm{CO}_{2}$ emissions. Since we now control for household size, we use non-equivalised disposable household income together with various household characteristics and relate them to the dependent variables - the natural logarithm of different types of $\mathrm{CO}_{2}$ emissions. The regression model excludes households with the highest and lowest percentile of emissions and income to minimise influence from outliers. We also exclude around 6 per cent of households with zero or negative home energy expenditure in all models to be able to compare the same sample of households (sample size 21,892). For transport emissions, we exclude all households without emissions (sample size 18,729) (see discussion in section 3.5).

As expected, income continues to play an important role for emissions in the full model, particularly again for transport emissions: a 1 per cent increase in income relates to a 0.60 per cent increase of transport emissions, 0.48 per cent of indirect but only 0.19 per cent of home energy emissions. Taking all three emission areas together, we find an income elasticity of 0.43 per cent.

For education we receive surprising results: high education remains to be positively and significantly related to emissions conditional on income. For transport, the education coefficient has the highest size: households in which at least one person has been in full time education for 16 years or more have on average 16.6 per cent higher emissions $(\exp (0.154))$ than households where none of the members participated in full-time education for more than 11 years. This compares to an increase by 11 per cent for indirect and 10 per cent for total but just 2 per cent for home energy. Therefore, our results do not confirm findings by Baiocchi et al. (2010: 62f.) who report a negative relationship between high education and total $\mathrm{CO}_{2}$ household emissions in the UK after controlling for income and other household characteristics.

Another interesting factor to examine is rural location. We have seen above that households in rural places are more likely to be in the highest emissions quartile - but might this simply be because people living in the countryside are richer on average than those living in cities? And if not, does living in a rural place contribute more to higher home energy emissions (detached and poorly insulated homes) or more to transport emissions? Our results show that living in a rural place is still significantly associated with higher emissions even after controlling for income for all three emission areas. The effect is strongest for transport emissions which are 16 per cent higher for rural than for urban households. Table A1 in the appendix shows the three transport mean emissions in separation, indicating that the 'effect' of rural location on transport emissions derives almost solely from motor fuel emissions: rural households have on average as much as a 22 per cent higher motor fuel 
emissions than urban households. This is surprisingly high given that we control for income and many other household characteristics. In contrast, rural location does not matter in terms of public transport emissions and for flight emissions we find a significant 5 per cent negative 'effect'. These results suggest that rural households would be particularly penalised from taxes on motor fuels, but less so from taxes on flights.

For indirect and home energy emissions, rural households have about 6 to 7 per cent higher emissions than those in urban areas. The 'impact' on indirect emissions might be related to other factors that we cannot investigate here, for instance, prices for goods and services might be higher in rural areas. However, in Table A2 in the appendix we also controlled for the type of dwelling given that they are likely to differ between urban and rural areas. Households living in detached houses have on average 28 per cent higher home energy emissions than households living in purpose built flats (this result is conditional on the number of bedrooms per dwelling). Once controlled for type of dwelling, rural households' home energy emissions are no longer significantly different to those in urban areas. This indicates that the higher proportion of detached houses in rural areas accounts for a significant part of the difference in rural and urban home energy emissions. Nevertheless, as will be discussed later using quantile regressions, the association between rural location and home energy emissions is more complicated than OLS regression results suggest.

While female headed households have lower transport emissions (the latter being due to lower motor fuel emissions, see Table A1 in the appendix), they have slightly higher home and indirect $\mathrm{CO}_{2}$ emissions than male headed households. This might be quite surprising. We used an interaction term for female household heads and income, which demonstrated that $\mathrm{CO}_{2}$ emissions rise significantly with rising income but less so for female than for male headed households.

Conditional on other characteristics and as we would expect (since they are likely to spend more time at home), workless households have higher home energy but lower transport emissions than other households. If they use transport, they have higher emissions due to public transport rather than private vehicle use (Table A1).

The results for the role of age are more complex to interpret because we use three age variables in the model (the same as introduced in section 3.5 for the logistic regression). Turning points and slope of increase differ for the three emission areas. The conditional transport and indirect emission curves are inversed u-shaped whilst the home energy curve has a near linear upwards shape, i.e. emissions are rising with age once all other factors are controlled for. In contrast, a decrease of indirect emissions is estimated to start at around 51 and for transport at around 50 years of age. This indicates that older people are generally less likely to have high total and transport emissions (given the early turning point), whilst their home energy demand stays high up to old age. 
This was also confirmed when we plotted the relationship between age and emissions, controlling for other variables (not shown). Whilst the curves for transport, indirect and total emissions were almost flat for age groups 30-70 and decreased slightly for those aged 80 and above, they increased slightly for those aged 80 and above for home energy emissions. Interestingly, once we included an interaction term between age groups and log income (instead of using the three age variables in Table 5, we compared people aged 40-59, 60-79 and 80+ with younger adults), we found that indirect, and even more so, home energy emissions increased more steeply for the age groups 40 to 59 and 60 to 79, compared to reference persons below the age of 40. As for higher rural indirect emissions discussed above, we could speculate that higher indirect emissions with rising income for households with older reference persons might result from older people's restricted opportunities to purchase cheaper products due to more limited mobility compared to younger households.

Alternatively, as they are more likely to have paid off their mortgage and may have fewer other family members to support, they may have more spare 'capacity' for consumption. The interaction 'effect' is quite high for home energy emissions, increasing by an additional 0.11 per cent for a one per cent income increase for people aged 60 to 79. This underlines the importance of home energy for elderly people. For transport, the age-income interaction was only significant for people aged 80 and above for whom transport emissions increased considerably less with income than for other age groups.

The LCF / EFS also includes information on social class measured by occupation status. However, this variable is missing for about one third of household reference persons. We did include this variable accepting a smaller sample size and found education still to be significant even conditional on social class.

\subsection{Who emits most? Quantile regression analysis}

So far, the analysis assumes that covariates like income, education and rural location relate equally to $\mathrm{CO}_{2}$ emissions across the $\mathrm{CO}_{2}$ distribution. For example, it is assumed that income has the same 'impact' on emissions for high and low emission households. However, it is important to check whether this really is the case or whether the association between some household characteristics and emissions becomes stronger (or weaker) when we focus on high rather than average emissions. This would tell us which household characteristics are particularly important for high emissions crucial if we are interested which types of households might bear especially high burdens of carbon taxes. Up to now, the literature has not examined whether the association between household characteristics and emissions differs for high, low and average emissions.

We therefore use quantile regression to explore separate parts of the emission distribution independently. Quantile regression optimise according to the specified emission quantile, such as 
the median, while the OLS regressions discussed before optimise the model according to the mean. Koenker and Hallock (2001) provide a detailed discussion of quantile regressions.

For each emissions area, we run nine quantile regressions focusing on the $10^{\text {th }}$, the $20^{\text {th }}$ up to the $90^{\text {th }}$ percentile of the household emission distribution. The sample size and the dependent and explanatory variables included were exactly the same as those used for the OLS regression presented in Table 5, making the OLS and quantile regression results comparable. In general, quantile regression results indicate that while the size of coefficients significantly changes for some variables across the emission distribution, the actual difference in size is often relatively small. This indicates that the choice of OLS regression is mostly a reasonable one, especially if the emphasis lies on total $\mathrm{CO}_{2}$ emissions. If we find significant changes of coefficients across the emissions distribution, they are generally most sizable for transport emissions, indicating that it does matter where households are situated within the transport emissions distribution to quantify the 'effect' of some factors.

In detail, age and belonging to a workless or ethnic minority household impacts relatively evenly across the emissions distribution. The role of gender decreases significantly, but in terms of size only marginally, the more we move to higher emission households for all three emission areas. We find the same pattern for the second adult dummy (but no clear and sizable pattern for all other household size dummies). OLS regression results showed that the second adult increases home energy by about 23 per cent compared to a single adult household conditional on other household characteristics. However, home energy emissions increase by 29 per cent with the second adult if we focus on the $10^{\text {th }}$ percentile of the emissions distribution but only by 17 per cent for households at the $90^{\text {th }}$ percentile. The change of coefficient size is similar for indirect and even stronger for transport emissions. Single adults in low emission households might engage in different behaviours compared to those in high emission households conditional on other characteristics: on average they might live in smaller accommodations or use less heating in contrast to two adult households at the low end of emissions whilst single adult households at the high end of emissions may live in larger properties or heat more, to the extent that they are more similar to two adult high emitters.

A similar explanation might hold for the steady decrease of the impact of income on emissions the further we move to high emission households for all three emission areas, particularly for transport. Figure 2 (a) presents on the $x$-axis the transport emission quantile at which the quantile regression was run (from the 10th to the 90th percentile of the log transport $\mathrm{CO}_{2}$ distribution) and on the $y$-axis the regression coefficient of the natural log of income. In addition, it provides the OLS estimate given in Table 5 (straight line). Dashed lines represent the 95 per cent confidence interval of the estimates. Results show clearly that the income elasticities are variable 
across the transport emission distribution: while OLS regressions show that a one per cent increase in income leads to a 0.60 per cent increase for mean transport emissions, this figure is significantly higher for households at the $10^{\text {th }}$ emissions percentile (1.13 per cent) compared to high emission households at the $90^{\text {th }}$ percentile (0.54).

High education also seems to make a greater relative difference to transport emissions at the low end of the emission distribution than at the high end of emissions: highly educated households are estimated to have 27 per cent higher transport emissions than low educated households at the $10^{\text {th }}$ percentile, but only 9 per cent higher emissions at the $90^{\text {th }}$ percentile. The latter is presented in Figure 2 (b). In contrast, 'increases' of total emissions related to high education are much more similar at the low and high end of the emission distribution, with 9.4 per cent at the $10^{\text {th }}$ and 12.0 per cent at the $90^{\text {th }}$ percentile.

Similarly, OLS regression cannot sufficiently capture the association between rural location and home energy emissions. When we focus on low home energy emission households (up to around the 30th percentile), rural households have similar or even significantly lower emissions than urban households conditional on other controlling factors. However, at the top of the distribution, rural households have significantly higher home energy emissions than urban ones (see Figure $2 \mathrm{c}$ ). Furthermore, the conditional coefficient for rural location is higher for home energy than that for transport emissions at the high end of the emission distribution with a 15 per cent increase for home energy and 8 per cent for transport at the $80^{\text {th }}$ percentile respectively - contrary to what we find using OLS (see table 5). However, once we control in addition for dwelling and heating type (see discussion above), rural location becomes insignificant for home energy emissions. The association between oil central heating and home energy emissions becomes much stronger for high than for mean emissions (the coefficients differ significantly at the 1 per cent level) and detached and semidetached houses also remain strongly associated (but the coefficient size is similar to that from OLS regression). This indicates that the stronger association between rural location and home energy emissions at the high end of emissions mainly results from greater occurrence of oil central heating in rural places whereas detached houses account for more of the variation at the mean of emissions as discussed above (table A2). As a consequence, quantile regressions reveal the much more complicated relationship between rural/urban location and emissions. 


\subsection{Emissions by poor and rich households}

In a final step of the analysis we examined whether the association between household characteristics and emissions differs for rich and poor households because we were interested to know which characteristics make poor households particularly vulnerable to carbon taxes and which groups amongst the rich are particularly responsible for emissions. For this purpose, we ran OLS regressions separately for these two groups, defining rich households as those with incomes at or above the $75^{\text {th }}$ percentile of equivalised income and poor households as those with incomes at or below the $25^{\text {th }}$ income percentile. Mean total emissions for poor households are 12.0 tonnes and 29.8 tonnes for rich households (see table A3).

Emissions in all domains rise more steeply with income for rich than for poor households whilst many other household characteristics are more important for poorer than for richer households' emissions. To illustrate, a one per cent increase of income increases total emissions by 0.46 per cent amongst rich, but only 0.30 per cent amongst the poor, controlling for all other household characteristics. The income coefficients are significantly different at the $1 \%$ level when we compare rich and poor households for all types of emissions apart from transport. This indicates that additional income is more likely to translate into higher consumption - and therefore emissions - for rich than for poor households (see table A4).

In contrast, the coefficients for household size, age, presence of children, education level, worklessness and gender are significantly higher for poorer than for richer households for some emissions domains. For example, a second adult increases indirect emissions by 41 per cent $((\exp (0.35))$ amongst the poor but only by 31 per cent amongst the rich (see table A4). Children also contribute more to a household's emissions for poor than for rich households, particularly when we focus on the role of the second child: conditional on all other factors, poor households with at least two children have around 16 per cent higher total and indirect emissions than those with only one child, whilst the second child only "increases" emissions by 7 and 5 per cent respectively for rich households (for both types of emissions, the coefficients for rich and poor are significantly different at the $5 \%$ level).

High education also has a significantly higher positive "effect" on emissions for poorer than for richer households: for poor households, total emissions of those with high education are 19 per cent higher than for those with lower levels of education, compared to just 5 per cent among rich households (the coefficients for the rich and poor are significantly different at the $1 \%$ level). For indirect and transport emissions, the difference is also significant and even higher with a 24 or 42 per cent increase amongst the poor and a 5 or 4 per cent increase amongst the rich respectively. 
This indicates that high education makes a greater difference to consumption and travel patterns amongst the poor than amongst the rich.

We need to add a cautionary note when comparing these results because we need to bear in mind that rich households' emissions are, on average, higher than poor households' emissions. This means that even though high education 'adds' more in relative terms to poor households' emissions compared to those of rich households, highly educated rich households still emit more than highly educated poor households. If we predict total $\mathrm{CO}_{2}$ emissions for poor households with high and low education, setting all other characteristics to the mean, the poor highly educated emit on average 12.4 tonnes $\mathrm{CO}_{2}$ per year and the poor low educated 10.4. This reflects an increase of 19 per cent. If we do the same for rich households, we receive 25.8 tonnes for the highly and 24.5 tonnes for the less educated, which reflects a 5 per cent increase - but from a much higher level than for poor households.

Female headed poorer households have around 20 per cent lower transport emissions than male headed households, compared to only 1 per cent for the rich (coefficient are significantly different at the $1 \%$ level). This suggests that female headed households might be less affected by carbon taxes on transport, especially so if they are poor.

We also find an interesting difference for old age (defined as households with heads aged 80 and over) which has a greater "negative effect" for richer than for poorer households: high old age decreases transport emissions by around 46 per cent and total emissions by 14 amongst the rich, but only by 16 and close to 0 per cent respectively amongst the poor (coefficients significantly different at the 1 and $5 \%$ level respectively). This might indicate that old age puts larger relative restrictions on rich than on poor households' emissions, for example due to decreased mobility. This makes sense because poor households are already emitting much less than their rich counterparts at a younger age so that old age decreases emissions less for poor than for rich households.

Finally, we tested whether the associations between emissions and household characteristics for poorer and richer households differ at the mean (OLS) and higher emissions $\left(75^{\text {th }}\right.$ percentile). This would have provided further information on the types of poor households that are particularly "vulnerable" to carbon taxes because of high emissions. Generally, the differences in coefficient sizes between poor and rich people that we reported above for mean emissions are similar for high emissions. The only significant differences (at the $1 \%$ level) that we found between coefficients at the mean and at the $75^{\text {th }}$ percentile of emissions relate to the role of income for poor households: at the high end of emissions amongst the poor, a one per cent increase of income only contributes to a 0.26 per cent increase in indirect emissions, compared to 0.36 at the mean. However, the effect sizes for the number of adults and children, high education and rural location 
for the rich and poor were not significantly different at the $75^{\text {th }}$ percentile of emissions compared to the mean. This means that when we focus at poor households, we can confine ourselves to analysing associations between household characteristics and emissions at the mean to identify characteristics that particularly contribute to their emissions.

\section{Conclusion}

The value added of this paper was to compare the association between household characteristics and carbon dioxide emission across four emission areas: home energy, indirect, transport and total emissions. Indeed, household characteristics are differently related to emissions in these areas, a topic highly relevant from a policy perspective: policies targeting a specific emission domain will affect different households in different ways.

First, low income households will be relatively less affected if policies lead to an increase of prices for different modes of transport compared to policies that tax home or indirect emissions. Nevertheless, emissions are regressively distributed across income in all three areas (for those who have expenditures/emissions in these areas).

Second, we find that household size is very differently related to home energy, indirect and transport emissions. Transport and indirect emissions double to triple for two adult households compared to single adult households (without children). Home energy emissions increase only by about half, indicating higher economies of scales in this area. Surprisingly, children add less to a household's $\mathrm{CO}_{2}$ emissions than expected for all areas we looked at. This is important for policies that involve emission permits or rebates since their implications will depend on the way in which they take household composition and its association with emissions into account.

Third, many emission reduction policies discussed include financial disincentives and hence try to instigate behavioural change by impacting on disposable household income. However, our regression results show that depending on different emission areas, household characteristics still remain significant once income is controlled for. This means that monetary policies, besides impacting differently on high and low income households, are likely to simultaneously affect households with specific characteristics depending on which emission area is targeted.

Conditional on income, female headed, workless and rural households have significantly higher home energy emissions than comparator households. For rural households, this is mainly due to a larger proportion of detached houses. Results also indicate that the elderly are likely to be hardest hit by policies taxing home energy (independent of the income effect of such policies discussed above) whilst they have significantly lower travel emissions, particularly at the high end of the emissions distribution. 
Policies that put a price on indirect emissions would mostly penalise larger households (if households size were not taken into account outright), as well as rural households. Higher educated households would also be affected as they tend to have about 17 per cent higher emissions in this area than less educated households, conditional on income. These characteristics are also particularly relevant for low income households, whilst they matter less for high income households.

Transport emissions were separated into motor fuel, public transport and flight emissions for our analysis. The results show that any policies increasing the cost of motor fuel emissions would hit rural households hardest who, even conditional on household income, have 22 per cent higher motor fuel emissions than urban households, at least when we focus on mean emissions. Any policies increasing the price of public transport emissions are likely to penalise workless households and households with non-white reference persons most. We showed that richer and more educated households have a higher probability of using air travel than low income, low educated, workless and rural households. The latter are therefore less likely to be affected by policies that tax flight emissions.

In addition, we used quantile regressions to examine whether household characteristics influence emissions differently if we compare high, average and low emission households. Results indicate that effect sizes can differ significantly for these different points of the emissions distribution where household size and income generally contribute less to higher than to average or lower emissions, whilst effect sizes for high education, rural location and worklessness generally increase when we focus on high emissions. Interestingly, rural location increases home energy emissions more than transport emissions at the high end of the emissions distribution, whilst the opposite is true when we focus at the mean, indicating that rural households may in fact be at least as affected by taxes on home energy emissions than by those on travel emissions. This shows that more detailed analysis at different ends of the emissions distribution can uncover different patterns of vulnerability to $\mathrm{CO}_{2}$ taxes as well as capacities for emissions reduction than normal OLS regression.

Finally, comparing results for poor and rich households showed that income increases and old age decreases household emissions significantly more for rich than for poor households whilst most other characteristics such as high education, old age, worklessness, household size and the presence of children mattered more for poorer than for richer households for total, indirect and transport emissions, indicating that these characteristics can play an important role for increasing or decreasing financial implications for poor households resulting from mitigation policies. 


\section{Tables and Figures}

Table 1: Mean and median annual household $\mathrm{CO} 2$ emissions in tonnes, per cent of total emission and per cent of households not having emissions by emission area

\begin{tabular}{|c|c|c|c|c|c|}
\hline & $\begin{array}{c}\text { Median } \\
\text { tonne }\end{array}$ & $\begin{array}{l}\text { Mean } \\
\text { tonne }\end{array}$ & $\begin{array}{l}\text { Standard } \\
\text { error } \\
\text { mean } \\
\text { tonne }\end{array}$ & $\begin{array}{c}\text { Per cent } \\
\text { of total } \\
\text { mean } \\
\mathrm{CO}_{2} \\
\text { emissions }\end{array}$ & $\begin{array}{c}\text { Per cent of } \\
\text { households } \\
\text { without } \\
\text { emissions }\end{array}$ \\
\hline Home energy total of which & 4.48 & 5.11 & 0.03 & 25.3 & 5.7 \\
\hline Gas & 2.35 & 2.49 & 0.02 & 12.3 & 22.8 \\
\hline Electricity & 1.84 & 2.09 & 0.01 & 10.4 & 8.1 \\
\hline Other home energy & 0.00 & 0.53 & 0.03 & 2.6 & 93.2 \\
\hline Transport total of which & 2.97 & 4.40 & 0.04 & 21.8 & 15.2 \\
\hline Motor fuels & 1.6 & 2.38 & 0.03 & 11.8 & 36.4 \\
\hline Flights & 0.00 & 1.13 & 0.02 & 5.6 & 59.0 \\
\hline Public transport & 0.00 & 0.89 & 0.02 & 4.4 & 50.2 \\
\hline Indirect total of which & 8.69 & 10.67 & 0.08 & 52.9 & 0.0 \\
\hline $\begin{array}{l}\text { Indirect home energy and } \\
\text { motor fuel emissions }\end{array}$ & 2.23 & 2.60 & 0.02 & 12.9 & 9.0 \\
\hline Food & 1.33 & 1.53 & 0.01 & 7.6 & 0.7 \\
\hline Catering/hotels & 0.69 & 1.11 & 0.01 & 5.5 & 11.6 \\
\hline Cars \& repairs & 0.05 & 0.40 & 0.01 & 2.0 & 39.5 \\
\hline Recreation & 0.33 & 0.77 & 0.03 & 3.8 & 3.7 \\
\hline Clothing & 0.23 & 0.66 & 0.01 & 3.3 & 32.6 \\
\hline Furniture, appliances, tools & 0.13 & 0.67 & 0.01 & 3.3 & 32.1 \\
\hline Personal care & 0.17 & 0.38 & 0.01 & 1.9 & 12.3 \\
\hline Other indirect & 1.53 & 2.54 & 0.03 & 12.6 & 0.0 \\
\hline Total & 17.13 & 20.18 & 0.13 & 100.0 & 0.0 \\
\hline
\end{tabular}

Note: For all emission areas households without emissions are included in the calculation. Standard error for mean tonne takes complex survey design (weighting and clustering) into account. Sample size is 24,446 households. 
Table 2: Households' annual mean $\mathrm{CO} 2$ emission by household size and emission area

\begin{tabular}{ll|l|l|l|l|}
\hline & & Total CO2 & $\begin{array}{l}\text { Home } \\
\text { energy }\end{array}$ & $\begin{array}{l}\text { Indirect } \\
\text { emissions }\end{array}$ & Transport \\
\hline & 1 adult & $10.9(0.11)$ & $3.6(0.04)$ & $5.5(0.07)$ & $1.8(0.03)$ \\
Households without & 2 adults & $21.4(0.18)$ & $5.3(0.05)$ & $11.2(0.12)$ & $4.9(0.06)$ \\
children only & 3 adults & $27.3(0.42)$ & $6.2(0.12)$ & $14.5(0.25)$ & $6.6(0.16)$ \\
& 4 adults & $33.9(0.84)$ & $6.9(0.20)$ & $18.1(0.51)$ & $8.9(0.34)$ \\
\hline & 1 child & $24.5(0.36)$ & $5.7(0.10)$ & $13.4(0.22)$ & $5.5(0.13)$ \\
Two adult households only & 2 children & $28.0(0.36)$ & $6.3(0.09)$ & $15.3(0.22)$ & $6.3(0.13)$ \\
& 3 children & $29.0(0.87)$ & $6.7(0.19)$ & $15.8(0.56)$ & $6.4(0.30)$ \\
\hline
\end{tabular}

Note: Standard errors taking complex survey design (weighting and clustering) into account are reported in parentheses. For all emission areas households with zero emissions are included in the calculation. 
Table 3: Percentage of households being a high and low emission household by household characteristics and emission area

\begin{tabular}{|c|c|c|c|c|c|c|c|c|}
\hline & Low CO2 & $\begin{array}{l}\mathrm{High} \\
\mathrm{CO} 2\end{array}$ & $\begin{array}{r}\text { Low } \\
\text { indirect }\end{array}$ & $\begin{array}{r}\text { High } \\
\text { indirect }\end{array}$ & $\begin{array}{r}\text { Low } \\
\text { home } \\
\text { energy }\end{array}$ & $\begin{array}{r}\text { High } \\
\text { home } \\
\text { energy }\end{array}$ & $\begin{array}{r}\text { Low } \\
\text { transport }\end{array}$ & $\begin{array}{r}\text { High } \\
\text { transport }\end{array}$ \\
\hline Low income & 53.4 & 6.7 & 54.0 & 6.5 & 39.6 & 17.0 & 51.5 & 7.2 \\
\hline High income & 4.4 & 51.0 & 4.6 & 51.2 & 15.3 & 34.9 & 7.0 & 48.6 \\
\hline Children in hh & 12.4 & 37.3 & 10.4 & 38.6 & 17.2 & 34.9 & 16.2 & 32.6 \\
\hline No children hh & 30.2 & 19.9 & 31.0 & 19.4 & 28.3 & 20.9 & 28.7 & 21.9 \\
\hline Age $<=35$ & 22.2 & 21.1 & 19.4 & 23.0 & 32.9 & 16.0 & 21.0 & 25.8 \\
\hline Age 36 to 64 & 17.1 & 33.8 & 16.8 & 33.5 & 20.9 & 30.9 & 17.2 & 32.3 \\
\hline Age $>=65$ & 43.7 & 9.5 & 46.6 & 8.7 & 27.6 & 19.5 & 44.4 & 9.0 \\
\hline Education $>=16$ & 9.0 & 43.9 & 8.7 & 43.9 & 19.0 & 32.5 & 8.9 & 42.9 \\
\hline Education<11 & 35.5 & 13.5 & 35.8 & 13.2 & 30.7 & 19.1 & 35.2 & 15.0 \\
\hline Rural area & 19.2 & 32.9 & 20.3 & 31.5 & 22.4 & 32.0 & 19.9 & 30.4 \\
\hline Urban area & 26.8 & 22.4 & 26.5 & 22.9 & 25.6 & 22.3 & 26.5 & 23.5 \\
\hline Workless hh & 50.8 & 8.1 & 49.8 & 8.2 & 42.2 & 17.8 & 48.8 & 9.1 \\
\hline In employment & 21.4 & 27.4 & 21.5 & 27.4 & 22.6 & 26.0 & 21.6 & 27.3 \\
\hline Female head & 34.4 & 16.8 & 34.3 & 17.0 & 28.9 & 20.8 & 34.7 & 17.1 \\
\hline Male head & 19.1 & 30.2 & 19.1 & 30.0 & 22.5 & 27.6 & 18.9 & 30.0 \\
\hline Not 'white' & 26.6 & 22.8 & 28.9 & 19.1 & 27.3 & 25.9 & 22.7 & 26.8 \\
\hline 'White' & 24.9 & 25.2 & 24.7 & 25.5 & 24.8 & 24.9 & 25.2 & 24.8 \\
\hline Detached & 8.7 & 45.8 & 10.2 & 43.9 & 10.9 & 43.5 & 13.6 & 39.6 \\
\hline Semi detached & 19.7 & 25.5 & 20.3 & 25.1 & 18.1 & 26.3 & 21.4 & 26.0 \\
\hline Terraced & 27.3 & 17.8 & 26.4 & 19.3 & 25.8 & 19.6 & 28.1 & 19.6 \\
\hline Flat converted & 44.0 & 13.5 & 42.5 & 14.8 & 48.0 & 8.5 & 32.0 & 17.3 \\
\hline Flat purpose & 53.3 & 7.3 & 51.4 & 8.0 & 54.4 & 7.0 & 43.3 & 12.2 \\
\hline
\end{tabular}

Note: Households with low emissions are those at or below the $25^{\text {th }}$ percentile of the emission distribution, while households with emissions above the $75^{\text {th }}$ percentile are called high emission households. Low income households have equivalised household income equal or below the $25^{\text {th }}$ percentile, high income households are situated at or above the $75^{\text {th }}$ percentile of the equivalised income distribution. For all emission areas households with zero emissions are included in the calculation. 
Table 4: Logistic regression results: probability to have transport emissions by transport emission area

\begin{tabular}{|c|c|c|c|c|}
\hline & Transport & Motor fuel & $\begin{array}{c}\text { Public } \\
\text { transport }\end{array}$ & Air travel \\
\hline \multirow[t]{2}{*}{ Ln income } & $0.753^{* * *}$ & $0.553 * * *$ & $0.376 * * *$ & $0.917 * * *$ \\
\hline & $(0.0455)$ & $(0.0365)$ & $(0.0295)$ & (0.0398) \\
\hline \multirow[t]{2}{*}{ Adult2 } & $0.767^{* * *}$ & $0.849 * * *$ & $0.181^{* * *}$ & $-0.107 * *$ \\
\hline & $(0.0531)$ & (0.0395) & $(0.0375)$ & $(0.0417)$ \\
\hline \multirow[t]{2}{*}{ Adult3 } & $0.532 * * *$ & $0.253 * * *$ & $0.572 * * *$ & $-0.163 * * *$ \\
\hline & $(0.151)$ & $(0.0751)$ & (0.0579) & $(0.0571)$ \\
\hline \multirow[t]{2}{*}{ Adult4 } & 0.350 & 0.135 & 0.161 & -0.00714 \\
\hline & $(0.354)$ & $(0.154)$ & $(0.115)$ & $(0.110)$ \\
\hline \multirow[t]{2}{*}{ Adult5+ } & $2.947^{*}$ & 0.0102 & 0.00820 & -0.133 \\
\hline & (1.579) & $(0.312)$ & $(0.240)$ & $(0.245)$ \\
\hline \multirow[t]{2}{*}{ Child1 } & 0.0367 & 0.0582 & 0.0391 & $-0.516 * * *$ \\
\hline & (0.0824) & (0.0557) & $(0.0466)$ & $(0.0473)$ \\
\hline \multirow[t]{2}{*}{ Child2 } & -0.102 & $0.139 * *$ & 0.000118 & $-0.155 * * *$ \\
\hline & $(0.111)$ & $(0.0692)$ & $(0.0577)$ & $(0.0587)$ \\
\hline \multirow[t]{2}{*}{ Child3+ } & -0.172 & -0.138 & 0.0659 & $-0.384 * * *$ \\
\hline & $(0.143)$ & $(0.0918)$ & $(0.0780)$ & $(0.0848)$ \\
\hline \multirow[t]{2}{*}{ Age } & $0.0749 * * *$ & $0.103^{* * *}$ & 0.00308 & $0.0395 * * *$ \\
\hline & (0.00968) & $(0.00764)$ & $(0.00706)$ & (0.00807) \\
\hline \multirow[t]{2}{*}{$\mathrm{Age}^{2} / 100$} & $-0.0881 * * *$ & $-0.101^{* * *}$ & $-0.0135^{*}$ & $-0.0447 * * *$ \\
\hline & (0.00949) & $(0.00762)$ & $(0.00720)$ & $(0.00808)$ \\
\hline \multirow[t]{2}{*}{ Age top coded $(80+)$} & $-0.419 * * *$ & $-0.571 * * *$ & -0.124 & $-0.596 * * *$ \\
\hline & $(0.0828)$ & $(0.0768)$ & $(0.0813)$ & $(0.0966)$ \\
\hline \multirow[t]{2}{*}{ Education 12-15 } & $0.393 * * *$ & $0.260 * * *$ & $0.182 * * *$ & $0.356^{* * *}$ \\
\hline & $(0.0613)$ & $(0.0428)$ & $(0.0368)$ & (0.0403) \\
\hline \multirow[t]{2}{*}{ Education 16+ } & $0.789 * * *$ & $0.154 * * *$ & $0.321 * * *$ & $0.687^{* * *}$ \\
\hline & (0.0915) & $(0.0521)$ & $(0.0427)$ & $(0.0482)$ \\
\hline \multirow[t]{2}{*}{ Missing education } & 0.0250 & 0.0277 & -0.0949 & $-0.143^{* *}$ \\
\hline & $(0.0687)$ & $(0.0644)$ & $(0.0651)$ & $(0.0696)$ \\
\hline \multirow[t]{2}{*}{ Workless hh } & $-0.377 * * *$ & $-0.557 * * *$ & $0.108 * *$ & $-0.299 * * *$ \\
\hline & $(0.0631)$ & $(0.0530)$ & $(0.0487)$ & $(0.0581)$ \\
\hline \multirow[t]{2}{*}{ Not 'white' } & $-0.288 * * *$ & $-0.544 * * *$ & $-0.140 * *$ & -0.0103 \\
\hline & $(0.0962)$ & $(0.0668)$ & $(0.0625)$ & $(0.0702)$ \\
\hline \multirow[t]{2}{*}{ Rural location } & $0.172 * * *$ & $0.624 * * *$ & $-0.414 * * *$ & $-0.165 * * *$ \\
\hline & $(0.0590)$ & $(0.0459)$ & $(0.0387)$ & $(0.0420)$ \\
\hline \multirow[t]{2}{*}{ Missing rural } & 0.0189 & $0.437 * * *$ & $-0.324 * * *$ & $-0.157 * *$ \\
\hline & $(0.0785)$ & $(0.0604)$ & $(0.0540)$ & $(0.0622)$ \\
\hline \multirow[t]{2}{*}{ Constant } & $-4.286 * * *$ & $-5.684 * * *$ & $-2.268 * * *$ & $-6.532 * * *$ \\
\hline & $(0.323)$ & $(0.250)$ & $(0.212)$ & $(0.272)$ \\
\hline Observations & 24,389 & 24,389 & 24,389 & 24,389 \\
\hline
\end{tabular}

Note: The table reports estimates of weighted parameters $\beta$ of the logistic regression model that is described in the text. Standard errors reported in parenthesis take complex survey design with clustering in primary sampling units into account. $* * * p<0.01, * * p<0.05, * p<0.1$

Cases with missing values in the independent variables are excluded. 
Table 5: OLS regression results with dependent variable being the natural logarithm of CO2 emission in tonnes by emission area

\begin{tabular}{|c|c|c|c|c|}
\hline & $\begin{array}{l}\text { Total CO2 } \\
\text { emissions }\end{array}$ & $\begin{array}{c}\text { Home energy } \\
\text { emissions }\end{array}$ & $\begin{array}{c}\text { Indirect } \\
\text { emissions }\end{array}$ & $\begin{array}{l}\text { Transport } \\
\text { emissions }\end{array}$ \\
\hline \multirow[t]{2}{*}{ Ln income } & $0.432 * * *$ & $0.187^{* * *}$ & $0.481^{* * *}$ & $0.598 * * *$ \\
\hline & $(0.00733)$ & (0.00869) & $(0.00792)$ & $(0.0163)$ \\
\hline \multirow[t]{2}{*}{ Adult2 } & $0.267 * * *$ & $0.203 * * *$ & $0.278^{* * *}$ & $0.322 * * *$ \\
\hline & (0.00849) & (0.0109) & (0.00898) & (0.0198) \\
\hline \multirow[t]{2}{*}{ Adult3 } & $0.111 * * *$ & $0.108 * * *$ & $0.115^{* * *}$ & $0.105 * * *$ \\
\hline & (0.00999) & $(0.0135)$ & $(0.0111)$ & $(0.0216)$ \\
\hline \multirow[t]{2}{*}{ Adult4 } & $0.0736 * * *$ & $0.0542 * *$ & $0.0694 * * *$ & $0.104 * * *$ \\
\hline & (0.0199) & $(0.0247)$ & $(0.0223)$ & (0.0396) \\
\hline \multirow[t]{2}{*}{ Adult5+ } & $0.110 * * *$ & $0.168 * * *$ & $0.113^{* *}$ & 0.0423 \\
\hline & $(0.0411)$ & $(0.0508)$ & (0.0474) & $(0.0837)$ \\
\hline \multirow[t]{2}{*}{ Child1 } & $0.0966 * * *$ & $0.168^{* * *}$ & $0.126 * * *$ & $-0.0637 * * *$ \\
\hline & $(0.00905)$ & $(0.0122)$ & $(0.00982)$ & (0.0198) \\
\hline \multirow[t]{2}{*}{ Child2 } & $0.0727 * * *$ & $0.0867 * * *$ & $0.0794 * * *$ & $0.0521 * *$ \\
\hline & $(0.0108)$ & $(0.0140)$ & (0.0117) & $(0.0246)$ \\
\hline \multirow[t]{2}{*}{ Child3+ } & $0.0605 * * *$ & $0.110 * * *$ & $0.0537 * * *$ & 0.00224 \\
\hline & (0.0153) & $(0.0202)$ & $(0.0161)$ & $(0.0348)$ \\
\hline \multirow[t]{2}{*}{ Age } & $0.0203 * * *$ & $0.0216 * * *$ & $0.0166^{* * *}$ & $0.0327^{* * *}$ \\
\hline & $(0.00153)$ & (0.00199) & $(0.00168)$ & $(0.00371)$ \\
\hline \multirow[t]{2}{*}{$\mathrm{Age}^{2} / 100$} & $-0.0188 * * *$ & $-0.0149 * * *$ & $-0.0160 * * *$ & $-0.0335^{* * *}$ \\
\hline & $(0.00154)$ & $(0.00200)$ & (0.00168) & $(0.00381)$ \\
\hline \multirow[t]{2}{*}{ Age top coded $(80+)$} & $-0.0877 * * *$ & 0.0331 & $-0.138 * * *$ & $-0.198 * * *$ \\
\hline & $(0.0164)$ & $(0.0210)$ & $(0.0176)$ & $(0.0442)$ \\
\hline \multirow{2}{*}{$\begin{array}{l}\text { Female headed } \\
\text { households }\end{array}$} & $0.0256 * * *$ & $0.0524 * * *$ & $0.0324 * * *$ & $-0.0881 * * *$ \\
\hline & $(0.00668)$ & $(0.00848)$ & $(0.00734)$ & $(0.0151)$ \\
\hline \multirow[t]{2}{*}{ Education $12-15$} & $0.0734 * * *$ & $0.0306 * * *$ & $0.0825 * * *$ & $0.0972 * * *$ \\
\hline & $(0.00780)$ & $(0.00997)$ & $(0.00830)$ & $(0.0176)$ \\
\hline \multirow[t]{2}{*}{ Education $16+$} & $0.0996 * * *$ & $0.0190 *$ & $0.103 * * *$ & $0.154 * * *$ \\
\hline & $(0.00879)$ & $(0.0115)$ & $(0.00965)$ & (0.0197) \\
\hline \multirow[t]{2}{*}{ Missing education } & $-0.0390 * * *$ & -0.0217 & $-0.0427 * * *$ & $-0.0906 * * *$ \\
\hline & $(0.0139)$ & $(0.0172)$ & $(0.0145)$ & $(0.0327)$ \\
\hline \multirow[t]{2}{*}{ Workless household } & -0.00918 & $0.0531 * * *$ & -0.0143 & $-0.169 * * *$ \\
\hline & (0.0119) & $(0.0145)$ & $(0.0127)$ & $(0.0298)$ \\
\hline \multirow[t]{2}{*}{ Not 'white' } & $-0.0701^{* * *}$ & -0.0104 & $-0.162 * * *$ & $0.0720 * *$ \\
\hline & $(0.0140)$ & $(0.0165)$ & $(0.0152)$ & $(0.0294)$ \\
\hline \multirow[t]{2}{*}{ Rural location } & $0.0880 * * *$ & $0.0585^{* * *}$ & $0.0693 * * *$ & $0.150 * * *$ \\
\hline & $(0.00804)$ & $(0.0110)$ & $(0.00884)$ & $(0.0149)$ \\
\hline \multirow[t]{2}{*}{ Missing rural } & $0.178 * * *$ & $0.207^{* * *}$ & $0.158 * * *$ & $0.0954 * * *$ \\
\hline & $(0.0121)$ & $(0.0203)$ & $(0.0116)$ & $(0.0222)$ \\
\hline \multirow[t]{2}{*}{ Constant } & $-0.578 * * *$ & $-0.575 * * *$ & $-1.468 * * *$ & $-3.472 * * *$ \\
\hline & $(0.0484)$ & $(0.0615)$ & $(0.0531)$ & $(0.112)$ \\
\hline Observations & 21,892 & 21,892 & 21,892 & 18,729 \\
\hline R-squared & 0.584 & 0.196 & 0.592 & 0.353 \\
\hline
\end{tabular}

Note: Results are weighted and standard errors presented in parentheses take clustering within primary sampling units into account $(* * * p<0.01, * * p<0.05, * p<0.1)$. Highest and lowest percentiles of the income and emission distribution were excluded from the analysis. 
Figure 1: Annual equivalised household income and household $\mathrm{CO} 2$ emissions by emission area (log - log scale)

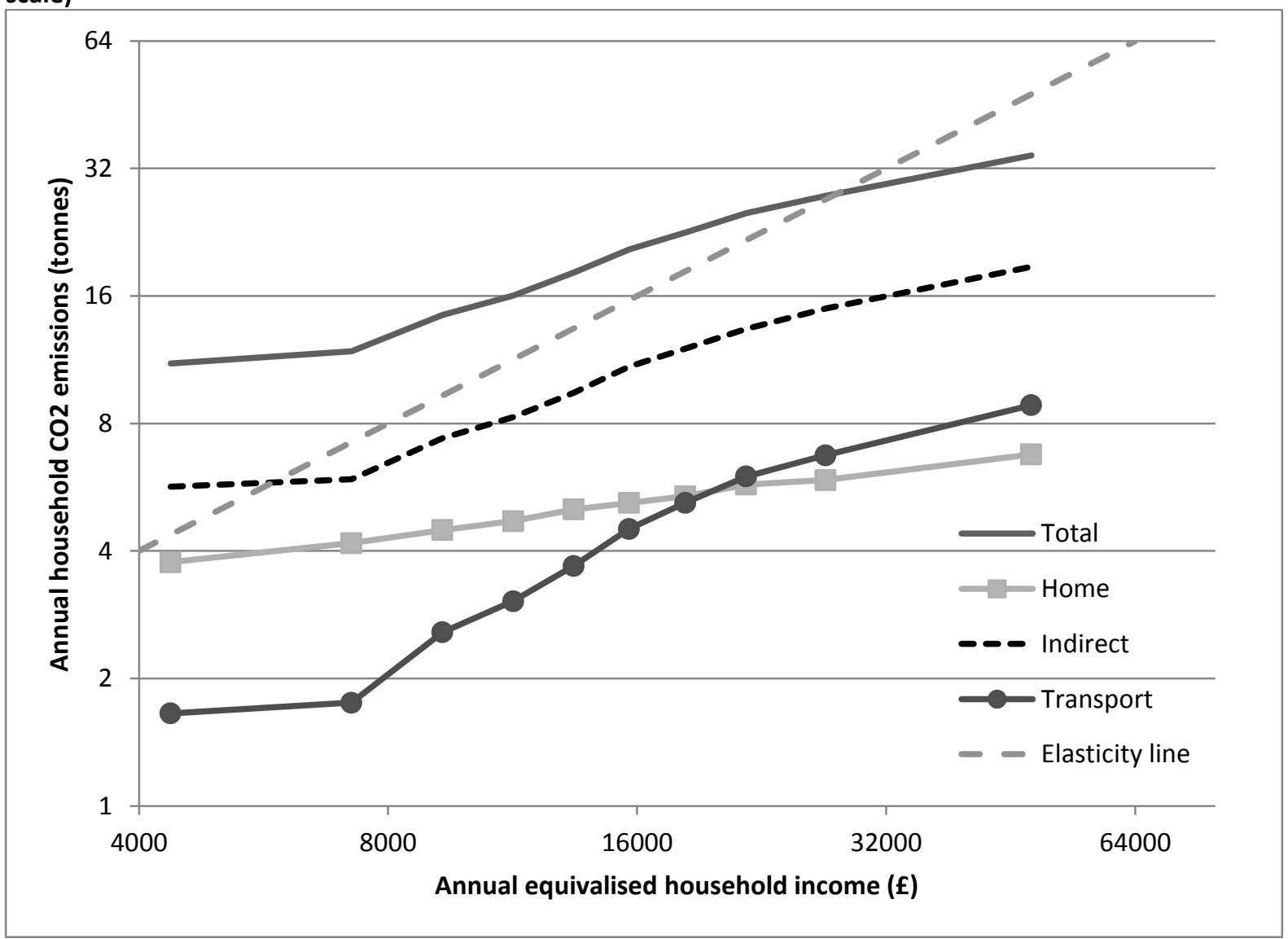

Note: The graph plots mean household $\mathrm{CO} 2$ emissions by mean income at each income decile on log scales. The dashed "elasticity" line shows a $1 \%$ increase in household $\mathrm{CO} 2$ emissions if income increases by $1 \%$. 
Figure 2: Ordinary least squares and quantile regression coefficients for some household characteristics and by different $\mathrm{CO} 2$ emission area

\section{(a)}

Log transport $\mathrm{CO} 2$ emissions regressed on In income

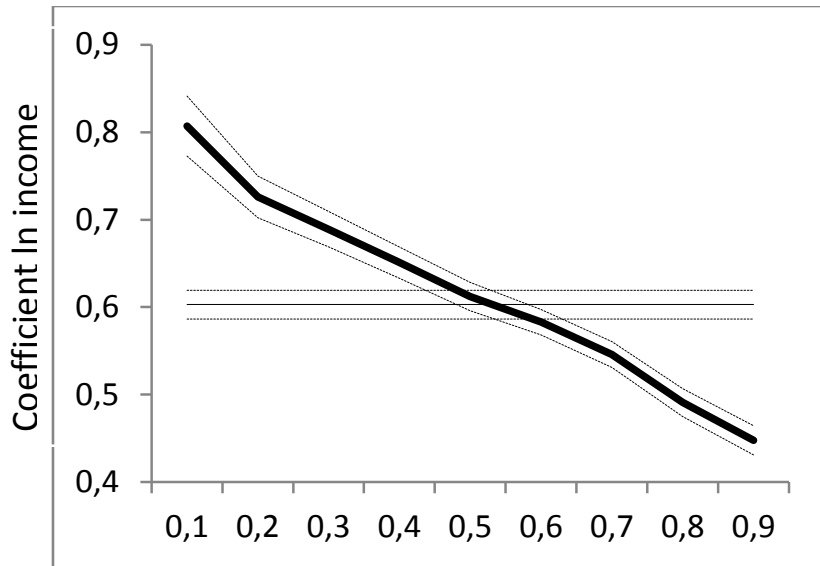

Quantile

(c)

Log CO2 home energy emissions regressed on rural area

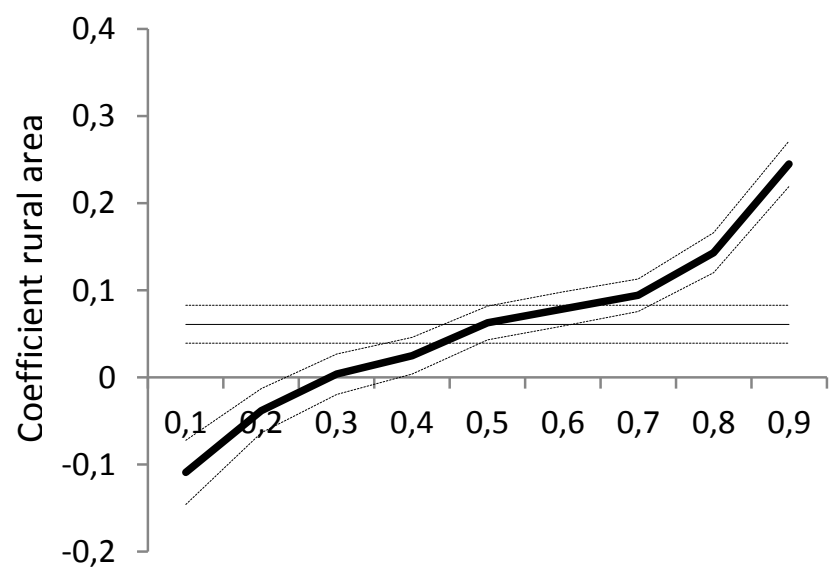

Quantile (b)

Log transport emissions regressed on household with at least one member having had 16 years of continuous education

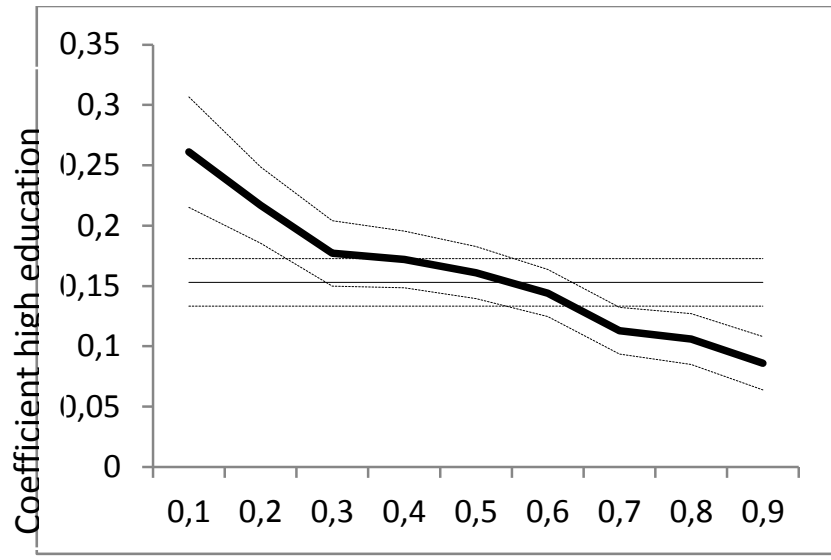

Quantile

(d)

Log CO2 transport emissions regressed on rural area

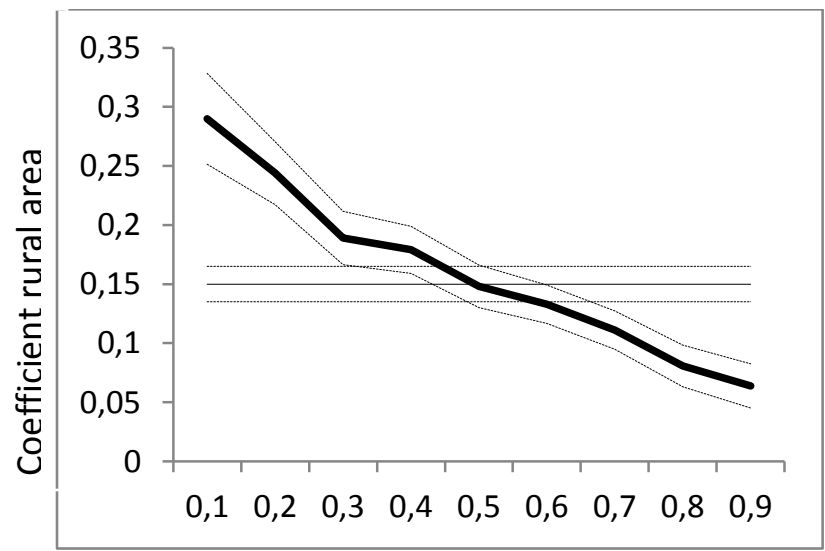

Quantile

Note: The $x$ axis presents the quantiles for that quantile regression were run. The $y$-axis presents the coefficient of the household characteristic given in the title to the graph. The straight line presents the OLS regression coefficient estimate given in Table 5. The dashed lines show the 95 per cent confidence interval around the estimates. Quantile regression controlled for the same variables as OLS regressions presented in Table 5. For calculating the confidence interval of the quantile regression coefficients clustering in primary sampling units is not taken into account. 


\section{Appendix}

Table A1: OLS regression with dependent variable being the natural logarithm of transport emissions by transport emission type

\begin{tabular}{|c|c|c|c|}
\hline & $\begin{array}{l}\text { Motor fuel } \\
\text { emissions }\end{array}$ & $\begin{array}{c}\text { Public } \\
\text { transport } \\
\text { emissions }\end{array}$ & $\begin{array}{c}\text { Flight } \\
\text { emissions }\end{array}$ \\
\hline \multirow[t]{2}{*}{ Ln income } & $0.308 * * *$ & $0.525^{* * *}$ & $0.308 * * *$ \\
\hline & $(0.0141)$ & $(0.0297)$ & $(0.0269)$ \\
\hline \multirow[t]{2}{*}{ Adult2 } & $0.150 * * *$ & $0.170 * * *$ & $0.411 * * *$ \\
\hline & $(0.0167)$ & $(0.0350)$ & $(0.0317)$ \\
\hline \multirow[t]{2}{*}{ Adult3 } & $0.136 * * *$ & $-0.0778 *$ & -0.0284 \\
\hline & $(0.0213)$ & $(0.0440)$ & (0.0409) \\
\hline \multirow[t]{2}{*}{ Adult4 } & $0.142 * * *$ & 0.110 & -0.0871 \\
\hline & $(0.0378)$ & (0.0815) & $(0.0768)$ \\
\hline \multirow[t]{2}{*}{ Adult5+ } & 0.0937 & -0.155 & 0.149 \\
\hline & $(0.0974)$ & $(0.164)$ & $(0.151)$ \\
\hline \multirow[t]{2}{*}{ Child1 } & 0.00485 & $-0.167 * * *$ & 0.0427 \\
\hline & (0.0191) & $(0.0380)$ & $(0.0361)$ \\
\hline \multirow[t]{2}{*}{ Child2 } & 0.00853 & -0.0164 & $0.139 * * *$ \\
\hline & $(0.0223)$ & (0.0469) & $(0.0471)$ \\
\hline \multirow[t]{2}{*}{ Child3 } & $0.0973^{* * *}$ & -0.0611 & 0.0130 \\
\hline & $(0.0301)$ & $(0.0687)$ & $(0.0699)$ \\
\hline \multirow{2}{*}{ Age } & $0.0192 * * *$ & -0.00899 & $0.0127 * *$ \\
\hline & $(0.00313)$ & $(0.00639)$ & $(0.00635)$ \\
\hline \multirow[t]{2}{*}{ Age2/100 } & $-0.0231 * * *$ & $0.0114^{*}$ & -0.0103 \\
\hline & $(0.00317)$ & $(0.00654)$ & $(0.00648)$ \\
\hline \multirow[t]{2}{*}{ Age top coded $(80+)$} & -0.0230 & $-0.150 *$ & $-0.216 * *$ \\
\hline & $(0.0341)$ & $(0.0770)$ & $(0.0848)$ \\
\hline \multirow[t]{2}{*}{ Female headed households } & $-0.0701 * * *$ & 0.0437 & -0.0370 \\
\hline & $(0.0136)$ & $(0.0293)$ & $(0.0251)$ \\
\hline \multirow[t]{2}{*}{ Education $12-15$} & $0.0421 * * *$ & $-0.0847 * *$ & 0.00568 \\
\hline & $(0.0154)$ & $(0.0350)$ & (0.0313) \\
\hline \multirow[t]{2}{*}{ Education 16+ } & $0.0645^{* * *}$ & $-0.0669 *$ & $0.109 * * *$ \\
\hline & $(0.0174)$ & $(0.0382)$ & $(0.0339)$ \\
\hline \multirow[t]{2}{*}{ Missing education } & $-0.0726 * * *$ & -0.0305 & -0.0526 \\
\hline & $(0.0256)$ & $(0.0604)$ & $(0.0632)$ \\
\hline \multirow[t]{2}{*}{ Workless households } & $-0.0526 * *$ & $0.150 * * *$ & $0.158^{* * *}$ \\
\hline & $(0.0250)$ & $(0.0473)$ & (0.0549) \\
\hline \multirow[t]{2}{*}{ Not white } & $-0.0612 * *$ & $0.165^{* * *}$ & $0.604 * * *$ \\
\hline & $(0.0298)$ & $(0.0487)$ & $(0.0408)$ \\
\hline \multirow[t]{2}{*}{ Rural location } & $0.196 * * *$ & 0.00976 & $-0.0515^{*}$ \\
\hline & $(0.0141)$ & $(0.0356)$ & $(0.0292)$ \\
\hline \multirow[t]{2}{*}{ Missing rural } & $0.195^{* * *}$ & -0.0221 & $-0.448 * * *$ \\
\hline & $(0.0204)$ & $(0.0433)$ & $(0.0436)$ \\
\hline \multirow[t]{2}{*}{ Constant } & $-1.411^{* * *}$ & $-3.305 * * *$ & $-2.282 * * *$ \\
\hline & $(0.0957)$ & $(0.207)$ & $(0.192)$ \\
\hline Observations & 14,736 & 10,478 & 9,028 \\
\hline R-squared & 0.212 & 0.073 & 0.130 \\
\hline
\end{tabular}

Note: Note to table 5 applies in the same way (i.e. exclusions are the same than for the regressions in table 5). 
Table A2: OLS regression with dependent variable being the natural logarithm of emissions by emission area

\begin{tabular}{|c|c|c|}
\hline & $\begin{array}{l}\text { Total CO2 } \\
\text { emissions }\end{array}$ & $\begin{array}{c}\text { Home energy } \\
\text { emissions }\end{array}$ \\
\hline Lnincome & $\begin{array}{l}0.358 * * * \\
(0.00722)\end{array}$ & $\begin{array}{l}0.103^{* * *} \\
(0.00853)\end{array}$ \\
\hline $\begin{array}{l}\text { Female headed } \\
\text { households }\end{array}$ & $\begin{array}{c}0.0304^{* * *} \\
(0.00633)\end{array}$ & $\begin{array}{c}0.0539 * * * \\
(0.00809)\end{array}$ \\
\hline Education 12-15 & $\begin{array}{c}0.0500 * * * \\
(0.00741)\end{array}$ & $\begin{array}{c}0.00792 \\
(0.00954)\end{array}$ \\
\hline Education $16+$ & $\begin{array}{c}0.0697^{* * *} \\
(0.00840)\end{array}$ & $\begin{array}{r}-0.00992 \\
(0.0109)\end{array}$ \\
\hline Missing education & $\begin{array}{c}-0.0350 * * * \\
(0.0125)\end{array}$ & $\begin{array}{l}-0.0155 \\
(0.0158)\end{array}$ \\
\hline Workless households & $\begin{array}{r}-0.00715 \\
(0.0112)\end{array}$ & $\begin{array}{c}0.0474 * * * \\
(0.0142)\end{array}$ \\
\hline Not white & $\begin{array}{c}-0.0362 * * * \\
(0.0128)\end{array}$ & $\begin{array}{c}0.0328 * * \\
(0.0151)\end{array}$ \\
\hline Rural location & $\begin{array}{c}0.0435 * * * \\
(0.00778)\end{array}$ & $\begin{array}{l}0.00120 \\
(0.0103)\end{array}$ \\
\hline Missing rural & $\begin{array}{c}0.0366 * * \\
(0.0177) \\
\end{array}$ & $\begin{array}{c}0.0348 \\
(0.0304)\end{array}$ \\
\hline Own outright & $\begin{array}{l}0.122 * * * \\
(0.00921)\end{array}$ & $\begin{array}{c}0.0498 * * * \\
(0.0118)\end{array}$ \\
\hline Own with mortgage & $\begin{array}{c}0.0998 * * * \\
(0.00835)\end{array}$ & $\begin{array}{c}0.0451 * * * \\
(0.0112)\end{array}$ \\
\hline Missing own & $\begin{array}{c}0.113 * * * \\
(0.0234)\end{array}$ & $\begin{array}{c}0.184^{* * *} \\
(0.0315)\end{array}$ \\
\hline Detached house & $\begin{array}{l}0.154 * * * \\
(0.0134)\end{array}$ & $\begin{array}{c}0.244^{* * *} \\
(0.0169)\end{array}$ \\
\hline Semi detached house & $\begin{array}{c}0.0782 * * * \\
(0.0119)\end{array}$ & $\begin{array}{c}0.171^{* * *} \\
(0.0152)\end{array}$ \\
\hline Terraced house & $\begin{array}{c}0.0365 * * * \\
(0.0115)\end{array}$ & $\begin{array}{c}0.132 * * * \\
(0.0146)\end{array}$ \\
\hline Converted flat & $\begin{array}{c}0.0356 \\
(0.0217) \\
\end{array}$ & $\begin{array}{c}0.0687^{* * * *} \\
(0.0248)\end{array}$ \\
\hline $\begin{array}{l}\text { Central heating } \\
\text { electricity }\end{array}$ & $\begin{array}{c}-0.159 * * * \\
(0.0126)\end{array}$ & $\begin{array}{c}-0.193 * * * \\
(0.0159)\end{array}$ \\
\hline Central heating oil & $\begin{array}{c}0.109 * * * \\
(0.0169)\end{array}$ & $\begin{array}{c}0.120 * * * \\
(0.0300)\end{array}$ \\
\hline Other heating & $\begin{array}{c}-0.116^{* * *} \\
(0.0136)\end{array}$ & $\begin{array}{c}-0.133^{* * *} \\
(0.0192)\end{array}$ \\
\hline Number bedroom & $\begin{array}{c}0.0670 * * * \\
(0.00416) \\
\end{array}$ & $\begin{array}{l}0.108 * * * \\
(0.00537) \\
\end{array}$ \\
\hline Constant & $\begin{array}{c}-0.0943^{* *} \\
(0.0476)\end{array}$ & $\begin{array}{l}-0.103^{*} \\
(0.0614)\end{array}$ \\
\hline Observations & 21,892 & 21,892 \\
\hline R-squared & 0.626 & 0.275 \\
\hline
\end{tabular}

Note: Note to table 5 applies in the same way. Results presented are conditional on age and household size. 'Own outright means that the household owns the property without mortgage, 'missing own' denotes that information on home ownership is not available, control group are households renting the property. The control group regarding dwelling are households in a purpose built flat and the control group for the heating variable are households with central gas heating. 
Table A3: Mean emissions for poor and rich households

\begin{tabular}{|l|rr|rr|rr|rr|r|}
\hline & Total & \multicolumn{2}{|c|}{ Indirect } & \multicolumn{2}{|c|}{ Home energy } & \multicolumn{2}{|c|}{ Transport } & n \\
\hline & Mean & SE & Mean & SE & Mean & SE & Mean & SE & \\
Rich & 29.8 & 0.3 & 16.2 & 0.2 & 6.2 & 0.1 & 7.4 & 0.1 & 5821 \\
Poor & 12.0 & 0.1 & 6.1 & 0.1 & 4.1 & 0.1 & 1.9 & 0.0 & 6231 \\
\hline
\end{tabular}

Note: Rich households are defined as those with equivalised income at or above the $75^{\text {th }}$ percentile of the income distribution and poor households with equivalised household income at or below the $25^{\text {th }}$ percentile of the income distribution. 
Table A4: OLS regression on log $\mathrm{CO} 2$ emissions comparing poor and rich households

\begin{tabular}{|c|c|c|c|c|c|c|c|c|}
\hline VARIABLES & $\begin{array}{c}\text { Total CO2 } \\
\text { Poor } \\
\end{array}$ & $\begin{array}{c}\text { Total CO2 } \\
\text { Rich } \\
\end{array}$ & $\begin{array}{l}\text { Indirect } \\
\text { Poor }\end{array}$ & $\begin{array}{l}\text { Indirect } \\
\text { Rich }\end{array}$ & $\begin{array}{c}\text { Home energy } \\
\text { Poor }\end{array}$ & $\begin{array}{c}\text { Home energy } \\
\text { Rich }\end{array}$ & $\begin{array}{c}\text { Transport } \\
\text { Poor }\end{array}$ & $\begin{array}{c}\text { Transport } \\
\text { Rich } \\
\end{array}$ \\
\hline Ln income & $\begin{array}{c}0.300 * * * \\
(0.0292)\end{array}$ & $\begin{array}{c}0.455^{* * *} \\
(0.0215)\end{array}$ & $\begin{array}{c}0.360 * * * \\
(0.0318)\end{array}$ & $\begin{array}{c}\mathbf{0 . 4 7 2} * * * \\
(0.0252)\end{array}$ & $\begin{array}{c}0.126 * * * \\
(0.0324)\end{array}$ & $\begin{array}{c}0.258 * * * \\
(0.0287)\end{array}$ & $\begin{array}{c}0.437 * * * \\
(0.0715)\end{array}$ & $\begin{array}{c}0.558 * * * \\
(0.0434)\end{array}$ \\
\hline Adult2 & $\begin{array}{c}0.320 * * * \\
(0.0216)\end{array}$ & $\begin{array}{c}0.272 * * * \\
(0.0171)\end{array}$ & $\begin{array}{c}0.347^{* * *} \\
(0.0222)\end{array}$ & $\begin{array}{c}\mathbf{0 . 2 6 8 * * *} \\
(0.0194)\end{array}$ & $\begin{array}{c}0.225 * * * \\
(0.0268)\end{array}$ & $\begin{array}{c}0.192 * * * \\
(0.0230)\end{array}$ & $\begin{array}{c}0.324 * * * \\
(0.0555)\end{array}$ & $\begin{array}{c}0.374 * * * \\
(0.0352)\end{array}$ \\
\hline Adult3 & $\begin{array}{c}0.153 * * * \\
(0.0332)\end{array}$ & $\begin{array}{c}0.103 * * * \\
(0.0168)\end{array}$ & $\begin{array}{c}0.150 * * * \\
(0.0341)\end{array}$ & $\begin{array}{c}0.103 * * * \\
(0.0198)\end{array}$ & $\begin{array}{c}0.153 * * * \\
(0.0416)\end{array}$ & $\begin{array}{c}0.0892 * * * \\
(0.0251)\end{array}$ & $\begin{array}{c}0.0799 \\
(0.0782)\end{array}$ & $\begin{array}{c}0.189 * * * \\
(0.0343)\end{array}$ \\
\hline Adult4+ & $\begin{array}{c}0.192^{* * *} \\
(0.0689)\end{array}$ & $\begin{array}{c}0.0973 * * * \\
(0.0271)\end{array}$ & $\begin{array}{c}0.195 * * * \\
(0.0714)\end{array}$ & $\begin{array}{c}0.111^{* * *} \\
(0.0308)\end{array}$ & $\begin{array}{c}0.0808 \\
(0.0737)\end{array}$ & $\begin{array}{c}0.0465 \\
(0.0425)\end{array}$ & $\begin{array}{c}0.428 * * * \\
(0.124)\end{array}$ & $\begin{array}{c}\mathbf{0 . 1 0 7 *} \\
(0.0597)\end{array}$ \\
\hline Child1 & $\begin{array}{c}0.119 * * * \\
(0.0283)\end{array}$ & $\begin{array}{c}0.104 * * * \\
(0.0160)\end{array}$ & $\begin{array}{c}0.131^{* * *} \\
(0.0299)\end{array}$ & $\begin{array}{c}0.164 * * * \\
(0.0180)\end{array}$ & $\begin{array}{c}0.159 * * * \\
(0.0341)\end{array}$ & $\begin{array}{c}0.161 * * * \\
(0.0226)\end{array}$ & $\begin{array}{l}-0.0635 \\
(0.0699)\end{array}$ & $\begin{array}{l}-0.0514 \\
(0.0330)\end{array}$ \\
\hline Child2+ & $\begin{array}{c}0.144 * * * \\
(0.0278)\end{array}$ & $\begin{array}{c}\mathbf{0 . 0 6 4 5 * * *} \\
(0.0199)\end{array}$ & $\begin{array}{c}0.147^{* * *} \\
(0.0291)\end{array}$ & $\begin{array}{c}0.0520 * * \\
(0.0225)\end{array}$ & $\begin{array}{c}0.143 * * * \\
(0.0329)\end{array}$ & $\begin{array}{c}0.102 * * * \\
(0.0282)\end{array}$ & $\begin{array}{c}0.189 * * * \\
(0.0670)\end{array}$ & $\begin{array}{l}0.0774 * \\
(0.0450)\end{array}$ \\
\hline Age & $\begin{array}{c}0.0243 * * * \\
(0.00319)\end{array}$ & $\begin{array}{c}\mathbf{0 . 0 1 2 2} * * * \\
(0.00340)\end{array}$ & $\begin{array}{c}0.0209 * * * \\
(0.00339)\end{array}$ & $\begin{array}{c}0.0119 * * * \\
(0.00381)\end{array}$ & $\begin{array}{c}0.0185^{* * *} \\
(0.00398)\end{array}$ & $\begin{array}{c}0.0247 * * * \\
(0.00443)\end{array}$ & $\begin{array}{c}0.0519 * * * \\
(0.00798)\end{array}$ & $\begin{array}{c}\mathbf{0 . 0 0 2 7 3} \\
(0.00716)\end{array}$ \\
\hline $\mathrm{Age}^{2} / 100$ & $\begin{array}{c}-0.0247^{* * *} \\
(0.00313)\end{array}$ & $\begin{array}{c}-0.00961 * * * \\
(0.00355)\end{array}$ & $\begin{array}{c}-0.0224 * * * \\
(0.00330)\end{array}$ & $\begin{array}{c}-0.0106 * * * \\
(0.00398)\end{array}$ & $\begin{array}{c}-0.0152 * * * \\
(0.00394)\end{array}$ & $\begin{array}{c}-0.0138 * * * \\
(0.00462)\end{array}$ & $\begin{array}{c}-0.0513 * * * \\
(0.00810)\end{array}$ & $\begin{array}{l}-0.00509 \\
(0.00751)\end{array}$ \\
\hline Age top coded $(80+)$ & $\begin{array}{l}-0.0165 \\
(0.0286)\end{array}$ & $\begin{array}{l}-0.156 * * \\
(0.0618)\end{array}$ & $\begin{array}{c}-0.0626 * * \\
(0.0298)\end{array}$ & $\begin{array}{l}-0.129 * \\
(0.0670)\end{array}$ & $\begin{array}{c}0.0730 * * \\
(0.0354)\end{array}$ & $\begin{array}{c}0.0493 \\
(0.0743)\end{array}$ & $\begin{array}{l}-0.179 * * \\
(0.0831)\end{array}$ & $\begin{array}{c}-0.623 * * * \\
(0.145)\end{array}$ \\
\hline $\begin{array}{l}\text { Female headed } \\
\text { households }\end{array}$ & $\begin{array}{l}0.0296 * \\
(0.0162)\end{array}$ & $\begin{array}{l}0.0230 * \\
(0.0117)\end{array}$ & $\begin{array}{c}0.0336 * * \\
(0.0167)\end{array}$ & $\begin{array}{c}0.0267 * * \\
(0.0133)\end{array}$ & $\begin{array}{c}0.0883 * * * \\
(0.0199)\end{array}$ & $\begin{array}{c}0.0419 * * * \\
(0.0158)\end{array}$ & $\begin{array}{c}-0.227^{* * *} \\
(0.0438)\end{array}$ & $\begin{array}{l}-0.00749 \\
(0.0250)\end{array}$ \\
\hline Education $12-15$ & $\begin{array}{c}0.0597^{* * *} \\
(0.0186)\end{array}$ & $\begin{array}{c}0.0321 * * \\
(0.0158)\end{array}$ & $\begin{array}{c}0.0739 * * * \\
(0.0196)\end{array}$ & $\begin{array}{c}0.0460 * * * \\
(0.0176)\end{array}$ & $\begin{array}{l}0.00767 \\
(0.0226)\end{array}$ & $\begin{array}{l}0.0326^{*} \\
(0.0197)\end{array}$ & $\begin{array}{l}0.125^{* *} \\
(0.0493)\end{array}$ & $\begin{array}{l}-0.0187 \\
(0.0344)\end{array}$ \\
\hline Education 16+ & $\begin{array}{c}0.173 * * * \\
(0.0310)\end{array}$ & $\begin{array}{c}\mathbf{0 . 0 5 1 1} * * * \\
(0.0152)\end{array}$ & $\begin{array}{c}0.216^{* * *} \\
(0.0316)\end{array}$ & $\begin{array}{c}0.0524 * * * \\
(0.0167)\end{array}$ & $\begin{array}{l}0.00757 \\
(0.0347)\end{array}$ & $\begin{array}{c}0.0233 \\
(0.0199)\end{array}$ & $\begin{array}{c}0.353 * * * \\
(0.0710)\end{array}$ & $\begin{array}{c}0.0375 \\
(0.0329)\end{array}$ \\
\hline Missing education & $\begin{array}{l}-0.00939 \\
(0.0242)\end{array}$ & $\begin{array}{l}-0.00695 \\
(0.0410)\end{array}$ & $\begin{array}{l}-0.0194 \\
(0.0249)\end{array}$ & $\begin{array}{l}0.00556 \\
(0.0457)\end{array}$ & $\begin{array}{l}0.00155 \\
(0.0293)\end{array}$ & $\begin{array}{c}0.0447 \\
(0.0527)\end{array}$ & $\begin{array}{l}-0.0139 \\
(0.0642)\end{array}$ & $\begin{array}{l}-0.178 * * \\
(0.0887)\end{array}$ \\
\hline Workless household & $\begin{array}{c}-0.0969 * * * \\
(0.0178)\end{array}$ & $\begin{array}{c}0.131 * * * \\
(0.0465)\end{array}$ & $\begin{array}{c}-0.0970 * * * \\
(0.0186)\end{array}$ & $\begin{array}{c}\mathbf{0 . 1 5 0 * * *} \\
(0.0578)\end{array}$ & $\begin{array}{l}-0.0130 \\
(0.0217)\end{array}$ & $\begin{array}{c}0.0155 \\
(0.0576)\end{array}$ & $\begin{array}{c}-0.307^{* * *} \\
(0.0465)\end{array}$ & $\begin{array}{l}0.181 * * \\
(0.0790)\end{array}$ \\
\hline Not white & $\begin{array}{c}-0.0666 * * * \\
(0.0249)\end{array}$ & $\begin{array}{l}-0.0522^{*} \\
(0.0278)\end{array}$ & $\begin{array}{c}-0.161^{* * *} \\
(0.0263)\end{array}$ & $\begin{array}{c}-0.128 * * * \\
(0.0328)\end{array}$ & $\begin{array}{l}-0.00448 \\
(0.0282)\end{array}$ & $\begin{array}{l}0.00849 \\
(0.0342)\end{array}$ & $\begin{array}{c}0.0681 \\
(0.0639)\end{array}$ & $\begin{array}{c}0.0248 \\
(0.0525)\end{array}$ \\
\hline
\end{tabular}




\begin{tabular}{|c|c|c|c|c|c|c|c|c|}
\hline Rural location & $\begin{array}{c}0.104 * * * \\
(0.0200)\end{array}$ & $\begin{array}{c}0.0779 * * * \\
(0.0131)\end{array}$ & $\begin{array}{c}0.0803 * * * \\
(0.0214)\end{array}$ & $\begin{array}{c}0.0577^{* * *} \\
(0.0145)\end{array}$ & $\begin{array}{c}0.0585^{* *} \\
(0.0245)\end{array}$ & $\begin{array}{c}0.0637 * * * \\
(0.0195)\end{array}$ & $\begin{array}{c}0.203 * * * \\
(0.0443)\end{array}$ & $\begin{array}{c}0.132 * * * \\
(0.0255)\end{array}$ \\
\hline \multirow[t]{2}{*}{ Missing rural } & $0.205^{* * *}$ & $0.139 * * *$ & $0.186 * * *$ & $0.123^{* * *}$ & $0.225^{* * *}$ & $0.211^{* * *}$ & $0.100 *$ & 0.0385 \\
\hline & $(0.0262)$ & $(0.0221)$ & $(0.0250)$ & $(0.0222)$ & $(0.0354)$ & $(0.0446)$ & $(0.0566)$ & (0.0383) \\
\hline \multirow[t]{2}{*}{ Constant } & 0.0635 & $-0.529 * * *$ & $-0.889 * * *$ & $-1.263 * * *$ & -0.0753 & $-1.217^{* * *}$ & $-3.071 * * *$ & $-2.453 * * *$ \\
\hline & $(0.160)$ & (0.149) & $(0.171)$ & $(0.176)$ & $(0.178)$ & $(0.194)$ & $(0.395)$ & $(0.306)$ \\
\hline Observations & 5,037 & 5,312 & 5,037 & 5,312 & 5,037 & 5,312 & 3,485 & 5,088 \\
\hline R-squared & 0.427 & 0.408 & 0.463 & 0.370 & 0.146 & 0.212 & 0.255 & 0.203 \\
\hline
\end{tabular}

Note: "Poor" households are defined as those in the lowest quartile of disposable income, "rich" households as those in the highest quartile of equivalised income. Bold coefficients are significantly different from those for "rich" households at the $5 \%$ level. Results are weighted and standard errors presented in parentheses take clustering within primary sampling units into account $(* * * p<0.01, * * p<0.05, * p<0.1)$. Highest and lowest percentiles of the income and emission distribution were excluded from the analysis. 


\section{References}

AA, 2006-2009. Fuel Price Reports. The Automobile Association, available from

http://www.theaa.com/motoring advice/fuel/fuel-price-archive.html, last accessed 21 July 2012.

Baer, P., Fieldman, G., Athanasiou, T., Kartha, S., 2008. Greenhouse Development Rights: towards an equitable framework for global climate policy. Cambridge Review of International Affairs 21, 649 - 669.

Baiocchi, G., Minx, J., Hubacek, K., 2010. The Impact of Social Factors and Consumer Behavior on Carbon Dioxide Emissions in the United Kingdom. Journal of Industrial Ecology 14, 50-72.

Brand, C., Boardman, B., 2008. Taming of the few - The unequal distribution of greenhouse gas emissions from personal travel in the UK. Energy Policy 36, 224-238.

Brand, C., Preston, J.M., 2010. '60-20 emission'-The unequal distribution of greenhouse gas emissions from personal, non-business travel in the UK. Transp. Policy 17, 9-19.

Buchs, M., Schnepf, S.V., 2013, From expenditure to emissions? Comparing three methods of estimating UK household emissions using expenditure data, to be published as S3RI working paper.

Burney, N.A., 1995. Socioeconomic development and electricity consumption A cross-country analysis using the random coefficient method. Energy Econ. 17, 185-195.

Cohen, C., Lenzen, M., Schaeffer, R., 2005. Energy requirements of households in Brazil. Energy Policy 33, 555562.

Deaton, A., Irish, M., 1984. Statistical models for zero expenditures in household budgets. Journal of Public Economics 23, 59-80.

DECC, 2011a. Average annual domestic electricity bills for selected towns and cities in the UK and average unit costs (QEP 2.2.3). Department of Energy and Climate Change, available from http://www.decc.gov.uk/en/content/cms/statistics/energy stats/prices/prices.aspx, accessed 21 July 2012.

DECC, 2011b. Average annual domestic gas bills for selected towns and cities in the UK and average unit costs (QEP 2.3.3). Department of Energy and Climate Change, available from http://www.decc.gov.uk/en/content/cms/statistics/energy stats/prices/prices.aspx, accessed 21 July 2012.

DECC, 2012. UK Emissions Statistics. 2010 final UK figures. Department of Energy and Climate Change, available from http://www.decc.gov.uk/en/content/cms/statistics/climate stats/gg emissions/uk emissions/uk e missions.aspx, last accessed 21 July 2012.

DECC, DEFRA, 2011. 2011 Guidelines to Defra / DECC's GHG Conversion Factors for Company Reporting. London: Department for Environment, Food and Rural Affairs and Department for Energy and Climate Change.

DEFRA, 2008. Distributional Impacts of Personal Carbon Trading. London: Department for Environment, Food and Rural Affairs, March 2008, online http://www.defra.gov.uk/environment/climatechange/uk/individual/carbontrading/pdf/pctdistributional-impacts.pdf, download 1 July 2008.

DfT, 2011. Average distance travelled by mode, Great Britain, since 1995/97. Department for Transport, available from http://www.dft.gov.uk/statistics/tables/nts0305/, last accessed 21 July 2012.

DRDNI, 2011. Travel Survey for Northern Ireland. In-Depth Report 2007-2009. Department for Regional Development Northern Ireland, available from http://www.drdni.gov.uk/index/statistics/statscatagories/stats-catagories-travel_survey.htm, last accessed 21 July 2012.

Dresner, S., Ekins, P., 2006. Economic instruments to improve UK home energy efficiency without negative social impacts. Fiscal Studies 27, 47-74.

Druckman, A., Jackson, T., 2008. Household energy consumption in the UK: A highly geographically and socioeconomically disaggregated model. Energy Policy 36, 3177-3192. 
Druckman, A., Jackson, T., 2009. The carbon footprint of UK households 1990-2004: A socio-economically disaggregated, quasi-multi-regional input-output model. Ecol. Econ. 68, 2066-2077.

DWP, 2011. Households Below Average Income (HBAI). An analysis of the income distribution 1994/952010/11. London: Department for Work and Pensions.

Fahmy, E., Thumim, J., White, V., 2011. The distribution of UK household CO2 emissions: Interim report. JRF programme paper: climate change and social justice, University of Bristol and Centre for Sustainable Energy.

Gibson, J., Kim, B., 2012. Testing the Infrequent Purchases Model Using Direct Measurement of Hidden Consumption from Food Stocks. Am. J. Agr. Econ. 94, 257-270.

Girod, B., De Haan, P., 2010. More or Better? A Model for Changes in Household Greenhouse Gas Emissions due to Higher Income. Journal of Industrial Ecology 14, 31-49.

Gough, I., Abdallah, S., Johnson, V., Ryan-Collins, J., Smith, C., 2011. The distribution of total greenhouse gas emissions by households in the UK, and some implications for social policy. CASE paper 152, Centre for Analysis of Social Exclusion, London: London School of Economics.

Herendeen, R., Tanaka, J., 1976. Energy cost of living. Energy 1, 165-178.

Herendeen, R.A., Ford, C., Hannon, B., 1981. Energy cost of living, 1972-1973. Energy 6, 1433-1450.

Hurth, V., 2010. Creating sustainable identities: the significance of the financially affluent self. Sustainable Development 18, 123-134.

Kerkhof, A.C., Benders, R.M.J., Moll, H.C., 2009. Determinants of variation in household CO2 emissions between and within countries. Energy Policy 37, 1509-1517.

Koenker, R., Hallock, K., 2001. Quantile regression. J. Econ. Perspect. 15, 143-156.

Larivière, I., Lafrance, G., 1999. Modelling the electricity consumption of cities: effect of urban density. Energy Econ. 21, 53-66.

Lenzen, M., Wier, M., Cohen, C., Hayami, H., Pachauri, S., Schaeffer, R., 2006. A comparative multivariate analysis of household energy requirements in Australia, Brazil, Denmark, India and Japan. Energy 31, 181-207.

O'Neill, B.C., Chen, B.S., 2002. Demographic determinants of household energy use in the United States. Popul. Dev. Rev. 28, 53-88.

Pachauri, S., 2004. An analysis of cross-sectional variations in total household energy requirements in India using micro survey data. Energy Policy 32, 1723-1735.

Paul, A., Wiedmann, T., Barrett, J., Minx, J., Scott, K., Dawkins, E., Owen, A., Briggs, J., Gray, I., 2010. Introducing the Resources and Energy Analysis Programme (REAP). Stockholm Environment Institute.

Reinders, A.H.M.E., Vringer, K., Blok, K., 2003. The direct and indirect energy requirement of households in the European Union. Energy Policy 31, 139-153.

Starkey, R., 2012. Personal carbon trading: A critical survey Part 1: Equity. Ecol. Econ. 73, 7-18.

Tiffin, R., Arnoult, M., 2010. The demand for a healthy diet: estimating the almost ideal demand system with infrequency of purchase. Eur. Rev. Agric. Econ. 37, 501-521.

Vringer, K., Blok, K., 1995. The direct and indirect energy requirements of households in the Netherlands. Energy Policy 23, 893-910.

Weber, C.L., Matthews, H.S., 2008. Quantifying the global and distributional aspects of American household carbon footprint. Ecol. Econ. 66, 379-391.

Wier, M., Lenzen, M., Munksgaard, J., Smed, S., 2001. Effects of Household Consumption Patterns on CO2 Requirements. Econ. Syst. Res. 13, 259 - 274. 